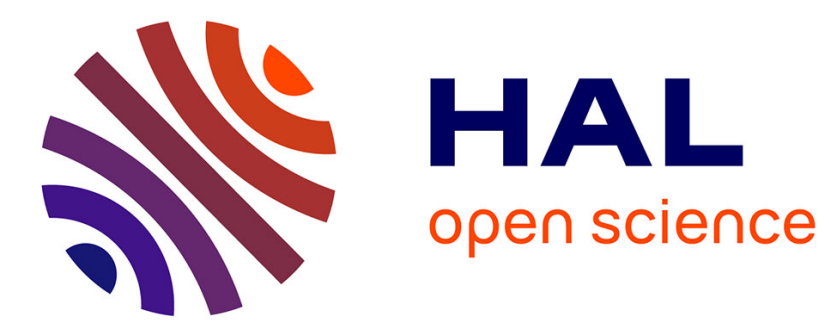

\title{
Combined effects of nanoparticles and other environmental contaminants on human health - an issue often overlooked
}

\author{
Valérie Forest
}

\section{- To cite this version:}

Valérie Forest. Combined effects of nanoparticles and other environmental contaminants on human health - an issue often overlooked. NanoImpact, 2021, 23, pp.100344. 10.1016/j.impact.2021.100344 . hal-03330798

\section{HAL Id: hal-03330798 \\ https://hal.science/hal-03330798}

Submitted on 1 Sep 2021

HAL is a multi-disciplinary open access archive for the deposit and dissemination of scientific research documents, whether they are published or not. The documents may come from teaching and research institutions in France or abroad, or from public or private research centers.
L'archive ouverte pluridisciplinaire HAL, est destinée au dépôt et à la diffusion de documents scientifiques de niveau recherche, publiés ou non, émanant des établissements d'enseignement et de recherche français ou étrangers, des laboratoires publics ou privés. 
Combined effects of nanoparticles and other environmental contaminants on human health - an issue often overlooked

\author{
Valérie Forest*
}

Mines Saint-Etienne, Univ Lyon, Univ Jean Monnet, INSERM, U1059 Sainbiose, Centre CIS, F-42023 Saint-Etienne, France.

*Corresponding author: Valérie Forest:

Mines Saint-Etienne, 158 cours Fauriel, CS 62362, 42023 Saint-Etienne Cedex 2. FRANCE.

Email: vforest@emse.fr 


\begin{abstract}
Air pollution is considered as a major public health issue worldwide. It consists of a complex mixture of pollutants including nanoparticles to which we are increasingly exposed to due to the dramatic development of the nanotechnologies and their incidental or intentional release in the environment. Consequently, some concerns have raised about the combined toxicity of air particulates and other air pollutants on human health. However, the interactions between the contaminants and their resulting combined toxicity are often overlooked. Indeed, the biological effects triggered by nanoparticles are usually assessed focusing on individual nanoparticles, while their interaction with co-contaminants can deeply impact, either positively or negatively, their biodistribution, fate in the organism and toxicological profile (additive, synergistic or antagonistic responses). This paper presents a bibliographic review on the combined toxicity of nanoparticles and co-pollutants and discusses the underlying mechanisms. It also highlights the scarcity of data in the current literature, arguing for an urgent need to take into account the mixture effects to be more representative of real-life conditions for a better and accurate human health risk assessment and management.
\end{abstract}

Key-words: inhaled particles; co-exposure; combined toxicity; human health; mixture of pollutants. 


\section{Introduction}

Humans are constantly exposed to a wide variety of pollutants, including nanoparticles to which we are increasingly exposed to due to the tremendous rise of the nanotechnologies and their incidental or intentional release in the environment. Consequently, some concerns have raised about the combined toxicity of airborne nanoparticles and other air pollutants on human health. However, the interactions between the contaminants and their resulting combined toxicity are often overlooked. The aim of this paper is to propose a bibliographic review on the joint toxicity of nanoparticles and co-pollutants to illustrate the lack of data in the current literature, arguing for the urgent need to carefully consider this issue. The underlying mechanisms of the joint toxicity of nanoparticles and co-pollutants are also discussed.

\subsection{Air pollution}

Air pollution is considered as a major public health issue worldwide. It is estimated that it is responsible for millions of premature deaths per year (Miller et al., 2012; Miller and Newby, 2020; Son et al., 2020; WHO, 2014). Ambient (outdoor) air pollution represents the $5^{\text {th }}$ biggest risk factor for all-cause mortality, above more well-recognized risk factors such as low exercise and poor diet, and the number one environmental risk factor (Miller and Newby, 2020). Initially, the effects of air pollution on the respiratory system received much attention as lungs are directly and constantly exposed to airborne pollutants. In addition, correlations between episodes of high air pollution and a worsening of allergic and inflammatory conditions of the lung, such as asthma and chronic obstructive pulmonary disease have been clearly evidenced (Miller et al., 2012). However, more recent studies highlighted clear relationships between air pollution and cardiovascular diseases, even claiming that cardiovascular conditions accounted for $40-60 \%$ of the premature mortality from air pollution (Beelen et al., 2014; Brunekreef and Holgate, 2002; Dockery et al., 1993; Germanova and Kernozhitskaya, 2017; Greim, 2019; 
Miller et al., 2012; Miller and Newby, 2020; Shah et al., 2013). Studies also suggested that childhood leukemia and diseases of the nervous system were related to air pollution (Amigou et al., 2011; Germanova and Kernozhitskaya, 2017).

Air pollution can be defined as a complex mixture of gaseous, volatile, semi-volatile and particulate matter (PM), containing organic and inorganic compounds (Guo et al., 2021; Miller et al., 2012; Miller and Newby, 2020). Methane, benzene, naphthalene, formaldehyde, polyaromatic hydrocarbons (PAHs), and alkanes are among the various semi-volatile organic chemicals of air pollution. The numerous gases found in ambient air include carbon dioxide $\left(\mathrm{CO}_{2}\right)$ and monoxide $(\mathrm{CO})$, ozone $\left(\mathrm{O}_{3}\right)$, nitrogen dioxide $\left(\mathrm{NO}_{2}\right)$ and sulphur dioxide $\left(\mathrm{SO}_{2}\right)$ (Miller et al., 2012; Miller and Newby, 2020). While these gases can induce adverse effects on human health, epidemiological studies reported that the PM contributed even more importantly to air pollution toxicity (Miller et al., 2012). PM is divided into coarse (PM10: particles with a diameter less than $10 \mu \mathrm{m}$ ), fine (PM2.5: particles with a diameter less than $2.5 \mu \mathrm{m}$ ) and ultrafine (PM0.1: particles with a diameter less than $100 \mathrm{~nm}$ ) particles. Because of their small size and large reactive surface area, ultrafine fractions can penetrate deeply into the lungs, reaching the alveoli and also potentially translocating in the bloodstream. Thus, they are acknowledged to produce greater effects (Miller et al., 2012; Miller and Newby, 2020). Moreover, ultrafine particles can adsorb high concentrations of toxic air pollutants leading to further harmful effects (Lu et al., 2015).

Due to the considerable rise of the nanotechnologies, engineered nanoparticles are increasingly used and incidentally or intentionally released in the environment. We are thus potentially increasingly exposed to these particles. Compared to ultrafine particles, less information is available regarding manufactured nanoparticles in terms of the toxicity induced after coexposure with other pollutants. However, as ultrafine particle and nanoparticle physicochemical features may overlap, it has been suggested that their behaviors and toxicities may also overlap 
(Stone et al., 2017). In addition, beside inhalation, nanoparticles can also enter the body through oral exposure and co-ingestion of nanoparticles and other pollutants such as pesticides for instance may also induce adverse effects on human health, especially on the gastro-intestinal tract (Cao et al., 2021, 2019; Dussert et al., 2020; Shi et al., 2010; Zheng et al., 2012). Moreover, nanoparticles incorporated in consumer products can be freed during the life cycle of the products, from their manufacture to their end-of-life. Especially, when this latter occurs through incineration, it can be accompanied by the formation of by-products which can impact deeply the release particle toxicity (Chalbot et al., 2017; Chivas-Joly et al., 2019, 2016; Singh et al., 2017). Consequently, some concerns have raised about the combined toxicity of air particulates and other air pollutants on human health.

\subsection{Poly-exposure issue}

As previously mentioned, it has been well documented that ambient air is a complex mixture of particles and air pollutants. However, their combined effects on human health remain unclear (Lu et al., 2015; Miller et al., 2012). Although constantly exposed to multiple sources of pollutants, the interactions between the contaminants and their resulting combined toxicity are poorly described in the literature. Indeed, the biological effects triggered by nanoparticles are usually assessed focusing on individual nanoparticles (Carlsten, 2018; Rosário et al., 2020). However, the nanoparticles released into the environment can interact with other pollutants or adsorb them on their surface, helping them enter in the organism (Abbas et al., 2020). This can lead to a significantly altered toxicological profile. This is why, although these interactions can be challenging to characterize, they should be carefully taken in consideration. Conversely, isolating the impact of a specific component present in a mixture and drawing firm conclusions on the health effects it induces can be complex (Miller and Newby, 2020). It has even been suggested that even if the toxicities of individual compounds are well characterized, unexpected 
adverse effects can be induced by the mixing of such compounds (Silins and Högberg, 2011; Zheng et al., 2012), arguing for a joint toxicity assessment (Yang et al., 2018). Even worse, compounds that do not trigger adverse effects individually can induce a significant toxicity when in mixture, resulting in an underestimation of the risk. This is perfectly exemplified by the study from Jiang et al. who assessed the combined toxicity of carboxylated black carbon and lead acetate on human bronchial epithelial cells at the no-observed-adverse-effect level (NOAEL). They demonstrated that co-exposure to these compounds could induce some unexpected toxicity, even beyond their known individual toxicities (Jiang et al., 2020).

The toxicological profile of a compound can be dramatically altered depending on a single or co-exposure with other agents. Interactions between the compounds may result in additive or synergistic effects. Indeed, for combined exposures the health effects may increase more than what would be expected from simply adding the effects of the individual components (Cedergreen, 2014). Antagonistic effects can also be observed (Asweto et al., 2017; Carlsten, 2018; Liu et al., 2018; Silins and Högberg, 2011).

Taken together, it highlights the need to consider pollutant combination, leading to "mixture toxicology” (Deville et al., 2016), not considering anymore pollutants individually but shifting to an integrated multipollutant approach (Yun et al., 2015). Only a better knowledge in this field will allow a better and reliable risk assessment/ management. A recent attempt to reach this objective relies on the study of the "exposome". This concept firstly introduced in 2005 by C.P. Wild (Wild, 2005), can be defined as the cumulative measure of environmental (i.e. non genetic) influences and the associated biological responses throughout the lifespan, including exposures from the environment, diet, behavior, and endogenous processes (Miller and Jones, 2014; Niedzwiecki et al., 2019; Vermeulen et al., 2020). Research on the human exposome is thus paramount to potentially understand the causal pathways leading to common diseases. Although the concept is very appealing, in practice, its development is extremely challenging. 
Unlike the genome, the exposome is a highly variable and dynamic entity that evolves throughout the lifetime of the individual. Advances will require increasing collaboration between epidemiologists, biostatisticians, experts in bioinformatics, and laboratory and environmental scientists (Miller and Jones, 2014; Wild, 2005).

\section{A literature review on the joint toxicity of nanoparticles and co-contaminants}

Studies on the combined toxicity of nanoparticles and other air pollutants are still scarce (Deng et al., 2017; Liu et al., 2018; Lu et al., 2017, 2015; Wu et al., 2016). To illustrate the lack of data on the joint toxicity and bioaccumulation of nanoparticles and co-contaminants a bibliographic review was carried out. Using PubMed, as a major search engine for papers on life sciences and biomedical topics, we queried the database with the following search terms: “(nanoparticles OR nanomaterials OR ultrafine particles) AND (mixture or co-exposure) AND toxicity AND human health". It turned out that 433 papers have been published on this topic by March 2021. By comparison, the same research without the terms (mixture OR co-exposure) resulted in 10112 references. As shown by Figure 1, very few papers were published until 2004 (less than 10 per year), but a rise in the number of publications was observed roughly in the last decade reaching almost 50 articles published each year during the last three years. 


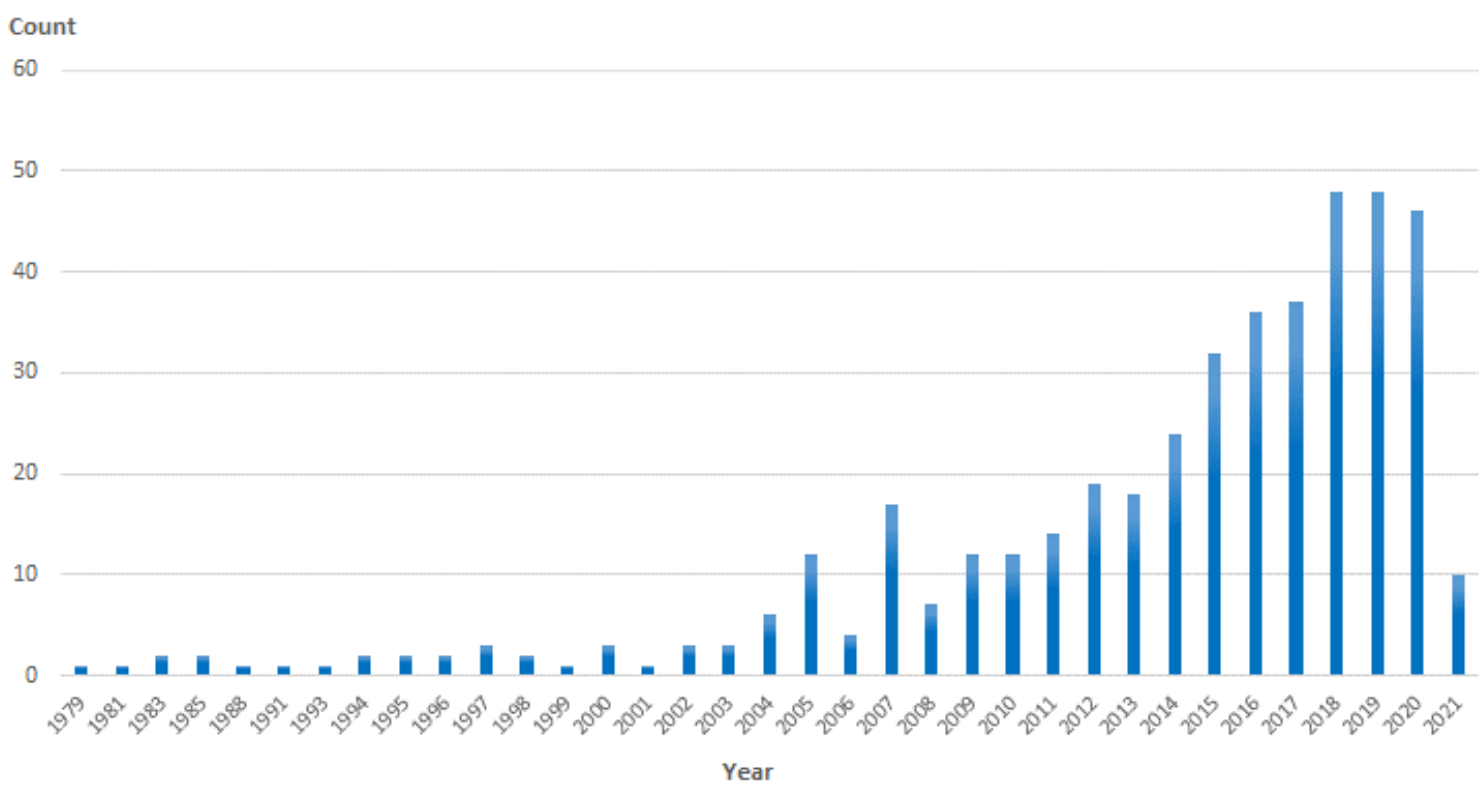

Figure 1 - Distribution of the 433 papers published per year.

Figure 2 schematically summarizes the selection process of the papers. We thoroughly reviewed the 433 articles focusing our attention on studies dealing with the toxicity induced by mixture of nanoparticles and co-pollutant by comparison with the effects induced by the same substance separately. We focused our attention on human health, we therefore excluded from our analysis studies dealing with plants and non-mammalian animal models, we also excluded reviews. We also focused on the issue of pollution and thus we excluded studies assessing nanoparticles and other components in the context of nanomedecine or environmental remediation (depollution with the use of nanoparticles to make the co-contaminant less available). We also excluded studies that did not include experimental data (i.e. studies based on digital, computing models for toxicity prediction). 


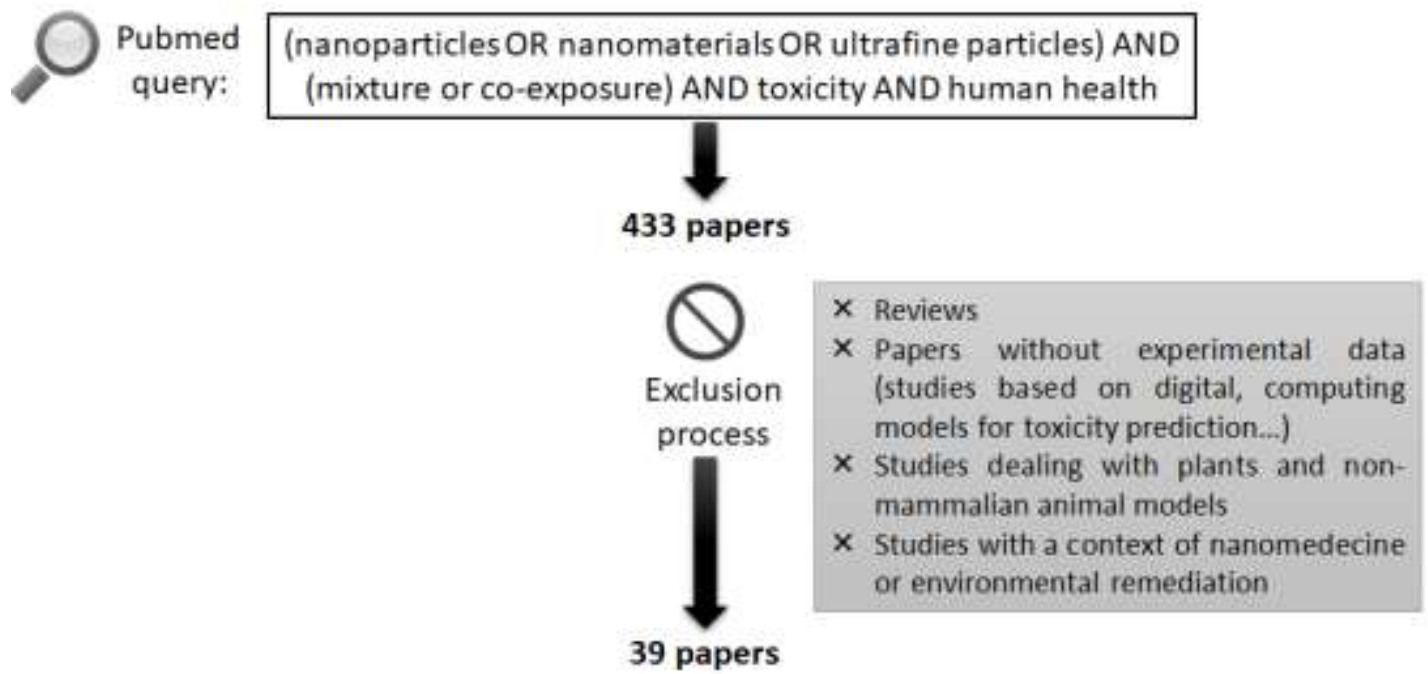

Figure 2 - Selection process of the papers.

Based on these criteria, we retained 39 publications. The list of these papers and their comprehensive analysis are reported in Table 1. The main results are summarized in Table 2. 
Table 1 - Analysis of the 39 publications selected from the literature review on the joint toxicity of nanoparticles and co-contaminants.

\section{Authors}

Title

\section{Type of mixture}

Biological model

Conclusions of the study
Conclusions

on the

observed

effects

\section{Studies targeting the respiratory system}

Combination effect of nanoparticles on the acute pulmonary inflammogenic potential: additive effect and antagonistic effect

Environmentally relevant iron oxide nanoparticles produce limited acute pulmonary effects in rats at realistic exposure levels

Guo et al. Autophagy changes in lung tissues of mice at 30 days after carbon blackmetal ion co-exposure

Toxicity of binary mixtures of $\mathrm{Al}(2) \mathrm{O}(3)$ and $\mathrm{ZnO}$ nanoparticles toward fibroblast and bronchial epithelium cells

Unravelling the potential cytotoxic effects of metal oxide nanoparticles and metal(loid) mixtures on A549 human cell line

Complex to simple: in vitro exposure of particulate matter simulated at the air-liquid interface discloses the health impacts of major air pollutants

Rosario et al.

Wang et al.
Binary mixtures of carbon black $(\mathrm{CB})$ nickel oxide $(\mathrm{NiO})$, and copper oxide (CuO) NPs Nano-sized iron oxide particles

$\left(\mathrm{Fe}_{3} \mathrm{O}_{4}, \alpha-\mathrm{Fe}_{2} \mathrm{O}_{3}\right.$ and $\gamma-\mathrm{Fe}_{2} \mathrm{O}_{3}$ )

Carbon black (CB) and $\mathrm{Ni}$

Zinc oxide $(\mathrm{ZnO})$ and aluminum oxide $\left(\mathrm{Al}_{2} \mathrm{O}_{3}\right) \mathrm{NPS}$

Binary mixtures of cerium oxide $\left(\mathrm{CeO}_{2}\right)$ NPs, titanium dioxide $\left(\mathrm{TiO}_{2}\right)$ NPs, mercury $(\mathrm{Hg})$ and arsenic (As)
Silica NPs and bisulfate
Rats

Rats and human

bronchial epithelial cells (BEAS-2B)
Additive effect of $\mathrm{CuO}$ and $\mathrm{NiO}$ NPs on the percentage of neutrophils and ROS generation potential. Antagonistic effect of a combined treatment with $\mathrm{CuO}$ or NiO NPs on the percentage of neutrophils.

None

(Guo et al., 2021)
No adverse effects observed.

Reference

Both (Lee et al.,

\section{Mice}

No adverse effects observed

None

(He et al.

Mouse fibroblast cells

(L929) and human

bronchial epithelial cells (BEAS-2B)

Cytotoxicity of binary mixtures of $\mathrm{Al}_{2} \mathrm{O}_{3}$ and

$\mathrm{ZnO}$ NPs produced greater effects compared to toxicity of either individual compound.

Additive/ 2020)
Lung epithelial cell line (A549)
Combined exposure of $\mathrm{TiO}_{2} \mathrm{NP}$ or $\mathrm{CeO}_{2} \mathrm{NP}$ mitigated As adverse effects. Only $\mathrm{CeO}_{2} \mathrm{NP}$ co- Antagonistic exposure reduced $\mathrm{Hg}$ toxicity.
Rosário et al., 2020)
Human bronchial epithelial cells (BEAS-2B)
Sulfate exacerbates the toxic effects of inhalable PMs.
Additive/ synergistic
(Wang et al., 


\begin{tabular}{|c|c|c|c|c|c|c|}
\hline Zeng et al. & $\begin{array}{c}\text { Cerium dioxide }(\mathrm{CeO}(2)) \text { nanoparticles } \\
\text { decrease arsenite }(\mathrm{As}(\mathrm{III})) \text { cytotoxicity } \\
\text { to } 16 \mathrm{HBE} 14 \mathrm{o}-\text { human bronchial } \\
\text { epithelial cells }\end{array}$ & $\begin{array}{l}\text { Cerium dioxide } \\
\left(\mathrm{CeO}_{2}\right) \mathrm{NPs} \text { and } \\
\text { arsenite }(\mathrm{As}(\mathrm{III}))\end{array}$ & $\begin{array}{l}\text { Human bronchial } \\
\text { epithelial cells } \\
(16 \mathrm{HBE} 14 \mathrm{o}-)\end{array}$ & $\begin{array}{c}\text { Co-exposure of } \mathrm{CeO}_{2} \mathrm{NPs} \text { and } \mathrm{As}(\mathrm{III}) \text { resulted } \\
\text { in reduced toxicity. }\end{array}$ & Antagonistic & $\begin{array}{l}\text { (Zeng et al., } \\
\text { 2018) }\end{array}$ \\
\hline Lu et al. & $\begin{array}{l}\text { Combined exposure to nano-silica and } \\
\text { lead induced potentiation of oxidative } \\
\text { stress and DNA damage in human lung } \\
\text { epithelial cells }\end{array}$ & $\begin{array}{l}\text { Silica NPs (nano- } \\
\left.\mathrm{SiO}_{2}\right) \text { and lead }(\mathrm{Pb})\end{array}$ & $\begin{array}{l}\text { Lung adenocarcinoma } \\
\text { cells (A549) }\end{array}$ & $\begin{array}{c}\text { Exposure to the combination of nano- } \mathrm{SiO}_{2} \text { and } \\
\mathrm{Pb} \text { potentiated oxidative stress and DNA } \\
\text { damage in A549 cells. }\end{array}$ & $\begin{array}{l}\text { Additive/ } \\
\text { synergistic }\end{array}$ & $\begin{array}{l}\text { (Lu et al., } \\
\text { 2015) }\end{array}$ \\
\hline Lehto et al. & $\begin{array}{l}\text { Co-exposure with fullerene may } \\
\text { strengthen health effects of organic } \\
\text { industrial chemicals }\end{array}$ & $\begin{array}{l}\text { Fullerene and } \\
\text { chemicals } \\
\text { (acetophenone, } \\
\text { benzaldehyde, benzyl } \\
\text { alcohol, m-cresol, } \\
\text { and toluene) }\end{array}$ & $\begin{array}{l}\text { Human THP-1- } \\
\text { derived macrophages }\end{array}$ & $\begin{array}{l}\text { Co-exposure to organic chemicals with } \\
\text { fullerene may strengthen the health effects of } \\
\text { the chemicals. }\end{array}$ & $\begin{array}{l}\text { Additive/ } \\
\text { synergistic }\end{array}$ & $\begin{array}{l}\text { (Lehto et al., } \\
\text { 2014) }\end{array}$ \\
\hline Wu et al. & $\begin{array}{l}\text { The chronic effect of amorphous silica } \\
\text { nanoparticles and benzo[a]pyrene co- } \\
\text { exposure at low dose in human } \\
\text { bronchial epithelial BEAS-2B cells }\end{array}$ & $\begin{array}{l}\text { Silica NPs (SiNPs) } \\
\text { and benzo[a]pyrene } \\
(\mathrm{B}[\mathrm{a}] \mathrm{P})\end{array}$ & $\begin{array}{l}\text { Human bronchial } \\
\text { epithelial cells } \\
\text { (BEAS-2B) }\end{array}$ & $\begin{array}{l}\text { Severe synergistic and additive toxic effects } \\
\text { induced by SiNPs and B[a]P co-exposure for } \\
\text { long-term in BEAS-2B cells even at low dose. }\end{array}$ & $\begin{array}{l}\text { Additive/ } \\
\text { synergistic }\end{array}$ & $\begin{array}{l}\text { (Wu et al., } \\
\text { 2019) }\end{array}$ \\
\hline Ahamed et al. & $\begin{array}{c}\text { Preventive effect of } \mathrm{TiO}(2) \\
\text { nanoparticles on heavy metal } \mathrm{Pb}- \\
\text { induced toxicity in human lung } \\
\text { epithelial (A549) cells }\end{array}$ & $\begin{array}{l}\mathrm{TiO}_{2} \mathrm{NPs}\left(\mathrm{nTiO}_{2}\right) \\
\text { and lead }(\mathrm{Pb})\end{array}$ & $\begin{array}{l}\text { Human lung epithelial } \\
\text { cells (A549) }\end{array}$ & $\begin{array}{l}\text { In the co-exposure group }\left(\mathrm{nTiO}_{2}+\mathrm{Pb}\right), \mathrm{nTiO}_{2} \\
\text { effectively attenuated the cytotoxicity, } \\
\text { oxidative stress and apoptotic responses of } \mathrm{Pb} \\
\text { in A549 cells. }\end{array}$ & Antagonistic & $\begin{array}{l}\text { (Ahamed et } \\
\text { al., 2019a) }\end{array}$ \\
\hline Wu et al. & $\begin{array}{c}\text { Co-exposure to amorphous silica } \\
\text { nanoparticles and benzo[a]pyrene at } \\
\text { low level in human bronchial epithelial } \\
\text { BEAS-2B cells }\end{array}$ & $\begin{array}{l}\text { Silica NPs (SiNPs) } \\
\text { and benzo[a]pyrene } \\
(\mathrm{B}[\mathrm{a}] \mathrm{P})\end{array}$ & $\begin{array}{l}\text { Bronchial epithelial } \\
\text { cells (BEAS-2B) }\end{array}$ & $\begin{array}{c}\text { Co-exposure to SiNPs and B[a]P exerts } \\
\text { synergistic and additive cytotoxic and } \\
\text { genotoxic effects. }\end{array}$ & $\begin{array}{l}\text { Additive/ } \\
\text { synergistic }\end{array}$ & $\begin{array}{l}\text { (Wu et al., } \\
\text { 2016) }\end{array}$ \\
\hline Yu et al. & $\begin{array}{l}\text { Combined toxicity of amorphous silica } \\
\text { nanoparticles and methylmercury to } \\
\text { human lung epithelial cells }\end{array}$ & $\begin{array}{l}\text { Silica NPs (nano- } \\
\mathrm{SiO}_{2} \text { ) and } \\
\text { methylmercury } \\
\quad(\mathrm{MeHg})\end{array}$ & $\begin{array}{l}\text { Lung adenocarcinoma } \\
\text { cells (A549) }\end{array}$ & $\begin{array}{l}\text { Additive and synergistic interactions were } \\
\text { responsible for the combined toxicity of nano- } \\
\qquad \mathrm{SiO}_{2} \text { and } \mathrm{MeHg} \text {. }\end{array}$ & $\begin{array}{l}\text { Additive/ } \\
\text { synergistic }\end{array}$ & $\begin{array}{c}\text { (Yu et al., } \\
\text { 2015) }\end{array}$ \\
\hline Ballesteros et al. & $\begin{array}{l}\text { Nanoceria, alone or in combination } \\
\text { with cigarette-smoke condensate, } \\
\text { induce transforming and epigenetic } \\
\text { cancer-like features in vitro }\end{array}$ & $\begin{array}{l}\text { Nanoceria and } \\
\text { cigarette smoke } \\
\text { condensate }\end{array}$ & $\begin{array}{l}\text { Human bronchial } \\
\text { epithelial cells } \\
\text { (BEAS-2B) }\end{array}$ & $\begin{array}{l}\text { Nanoceria exposure shows a positive } \\
\text { interaction with the cell-transforming effects of } \\
\text { cigarette smoke condensate. }\end{array}$ & $\begin{array}{l}\text { Additive/ } \\
\text { synergistic }\end{array}$ & $\begin{array}{l}\text { (Ballesteros et } \\
\text { al., 2021) }\end{array}$ \\
\hline
\end{tabular}




\begin{tabular}{|c|c|c|c|c|c|c|}
\hline Ahamed et al. & $\begin{array}{l}\text { Single-walled carbon nanotubes } \\
\text { attenuate cytotoxic and oxidative stress } \\
\text { response of } \mathrm{Pb} \text { in human lung } \\
\text { epithelial (A549) cells }\end{array}$ & $\begin{array}{l}\text { Single-walled carbon } \\
\text { nanotubes } \\
\text { (SWCNTs) and lead } \\
(\mathrm{Pb})\end{array}$ & $\begin{array}{l}\text { Human lung epithelial } \\
\text { cells (A549) }\end{array}$ & $\begin{array}{l}\text { SWCNTs attenuated the cytotoxic and } \\
\text { oxidative stress response generated by } \mathrm{Pb} \\
\text { exposure in A549 cells. }\end{array}$ & Antagonistic & $\begin{array}{l}\text { (Ahamed et } \\
\text { al., 2020b) }\end{array}$ \\
\hline Jiang et al. & $\begin{array}{l}\text { Low-dose combined exposure of } \\
\text { carboxylated black carbon and heavy } \\
\text { metal lead induced potentiation of } \\
\text { oxidative stress, DNA damage, } \\
\text { inflammation, and apoptosis in BEAS- } \\
\text { 2B cells }\end{array}$ & $\begin{array}{l}\text { Carboxylated black } \\
\text { carbon }(\mathrm{c}-\mathrm{BC}) \text { and } \\
\text { lead acetate }(\mathrm{Pb})\end{array}$ & $\begin{array}{l}\text { Human bronchial } \\
\text { epithelial cells } \\
\text { (BEAS-2B) }\end{array}$ & $\begin{array}{l}\text { Combination of c-BC and } \mathrm{Pb} \text { could } \\
\text { significantly increase cytotoxicity. }\end{array}$ & $\begin{array}{l}\text { Additive/ } \\
\text { synergistic }\end{array}$ & $\begin{array}{l}\text { (Jiang et al., } \\
\text { 2020) }\end{array}$ \\
\hline Son et al. & $\begin{array}{l}\text { Effects of antioxidants on oxidative } \\
\text { stress and inflammatory responses of } \\
\text { human bronchial epithelial cells } \\
\text { exposed to particulate matter and } \\
\text { cigarette smoke extract }\end{array}$ & $\begin{array}{l}\text { PM10 and cigarette } \\
\text { smoke extract (CSE) }\end{array}$ & $\begin{array}{l}\text { Human bronchial } \\
\text { epithelial cells } \\
\text { (BEAS-2B) }\end{array}$ & $\begin{array}{l}\text { Exposure of epithelial cells to PM or CSE } \\
\text { induced cytotoxicity, inflammation, and } \\
\text { oxidative stress, all of which were dramatically } \\
\text { increased when cells were exposed to the } \\
\text { combination of CSE and PM. }\end{array}$ & $\begin{array}{l}\text { Additive/ } \\
\text { synergistic }\end{array}$ & $\begin{array}{c}\text { (Son et al., } \\
2020)\end{array}$ \\
\hline Azari et al. & $\begin{array}{l}\text { Additive toxicity of co-exposure to } \\
\text { pristine multi-walled carbon nanotubes } \\
\text { and benzo } \alpha \text { pyrene in lung cells }\end{array}$ & $\begin{array}{l}\text { Pristine multi-walled } \\
\text { carbon nanotubes (P- } \\
\text { MWCNTs) and } \\
\text { benzo } \alpha \text { pyrene } \\
(\mathrm{BaP})\end{array}$ & $\begin{array}{l}\text { Human epithelial lung } \\
\text { cells (A549) }\end{array}$ & $\begin{array}{l}\text { The co-exposure to P-MWCNTs and BaP } \\
\text { enhanced the cytotoxicity compared to } \\
\text { exposure to P-MWCNTs and BaP individually, } \\
\text { but not statistically significant. }\end{array}$ & $\begin{array}{l}\text { Additive/ } \\
\text { synergistic }\end{array}$ & $\begin{array}{l}\text { (Azari et al., } \\
\text { 2020) }\end{array}$ \\
\hline Azari et al. & $\begin{array}{c}\text { Antagonistic effect of co-exposure to } \\
\text { short-multiwalled carbon nanotubes } \\
\text { and benzo[a]pyrene in human lung } \\
\text { cells (A549) }\end{array}$ & $\begin{array}{l}\text { Short-multiwalled } \\
\text { carbon nanotubes (S- } \\
\text { MWCNTs) and } \\
\text { benzo a pyrene (BaP) }\end{array}$ & $\begin{array}{l}\text { Human epithelial lung } \\
\text { cells (A549) }\end{array}$ & $\begin{array}{l}\text { Co-exposure to S-MWCNTs and BaP } \\
\text { demonstrated a significant reduction in ROS } \\
\text { generation and apoptosis compared with the } \\
\text { sum of their separate toxic effects at the same } \\
\text { concentrations. }\end{array}$ & Antagonistic & $\begin{array}{l}\text { (Azari et al., } \\
\text { 2019) }\end{array}$ \\
\hline Azari et al. & $\begin{array}{l}\text { Individual and combined toxicity of } \\
\text { carboxylic acid functionalized multi- } \\
\text { walled carbon nanotubes and benzo a } \\
\text { pyrene in lung adenocarcinoma cells }\end{array}$ & $\begin{array}{l}\text { Acid functionalized } \\
\text { multi-walled carbon } \\
\text { nanotubes (F- } \\
\text { MWCNTs) and } \\
\text { benzo a pyrene (BaP) }\end{array}$ & $\begin{array}{l}\text { Human epithelial lung } \\
\text { cells (A549) }\end{array}$ & $\begin{array}{c}\text { Combined exposure to F-MWCNTs and BaP } \\
\text { decreases cytotoxicity compared to individual } \\
\text { exposure. }\end{array}$ & Antagonistic & $\begin{array}{l}\text { (Rezazadeh } \\
\text { Azari et al., } \\
\text { 2019) }\end{array}$ \\
\hline Yun et al. & $\begin{array}{l}\text { Synergistic effects of particulate matter } \\
\text { (PM10) and } \mathrm{SO}_{2} \text { on human non-small } \\
\text { cell lung cancer A549 via ROS- } \\
\text { mediated NF- } \mathrm{kB} \text { activation }\end{array}$ & $\begin{array}{l}\text { Particulate matter } 10 \\
\text { (PM10) and sulfur } \\
\text { dioxide }\left(\mathrm{SO}_{2}\right)\end{array}$ & $\begin{array}{l}\text { Human lung } \\
\text { adenocarcinoma cells } \\
\text { (A549) }\end{array}$ & $\begin{array}{c}\text { The concomitant treatment of } \mathrm{PM} 10 \text { and } \mathrm{SO}_{2} \\
\text { led to synergistic injury. }\end{array}$ & $\begin{array}{l}\text { Additive/ } \\
\text { synergistic }\end{array}$ & $\begin{array}{l}\text { (Yun et al., } \\
\text { 2015) }\end{array}$ \\
\hline
\end{tabular}




\section{Studies targeting the digestive system}

Zheng et al. nanoparticles with bisphenol A on their

Shi Y et al.

Effects of the interaction of $\mathrm{TiO}_{2}$

physicochemical properties and in vitro toxicity

Synergistic genotoxicity caused by low concentration of titanium dioxide nanoparticles and p,p'-DDT in human hepatocytes

$\mathrm{TiO}_{2} \mathrm{NPs}$ (nano-

$\mathrm{TiO}_{2}$ ) and bisphenol A (BPA)

Titanium dioxide

NPs (nano- $\mathrm{TiO}_{2}$ ) and

dichlorodiphenyltrich

loroethane ( $\mathrm{p}, \mathrm{p}^{\prime}-$ DDT)

Co-exposure to $\mathrm{SiO}(2)$ nanoparticles and arsenic Induced augmentation of oxidative stress and mitochondriadependent apoptosis in human cells

Toxicity to RAW264.7 macrophages of silica nanoparticles and the E551 food additive, in combination with genotoxic agents

$\mathrm{TiO}(2)$ nanoparticles potentiated the cytotoxicity, oxidative stress and apoptosis response of cadmium in two different human cells

Human embryo

hepatocytes (L-02) toxicity.

Additive/ synergistic

(Zheng et al. 2012)

Human embryo

hepatocytes (L-02)

Dose-dependent synergistic genotoxicity induced by combined exposure of trace $\mathrm{p}, \mathrm{p}^{\prime}$ DDT and nano- $\mathrm{TiO}_{2}$.

Additive/ (Shi et al., synergistic 2010)

Human liver

Silica NPs $\left(\mathrm{nSiO}_{2}\right)$

and $\operatorname{arsenic}(\mathrm{As})$

3 types of silica NPs

(LS30, E551, fumed silica) and benzo[a]pyrene

$(\mathrm{B}[\mathrm{a}] \mathrm{P})$ and methane methylsulfonate

$$
\text { (MMS) }
$$

Titanium dioxide

NPs $\left(\mathrm{nTiO}_{2}\right)$ and cadmium $(\mathrm{Cd})$ cells colorectal
(HepG2) and human fibroblast (HT1080)

Mouse macrophages (RAW 264.7) and adenocarcinoma cells (Caco-2/ HT29-

MTX coculture)
Human liver (HepG2) and breast cancer (MCF-7) cells
Co-exposure of a non-cytotoxic concentration of $\mathrm{nSiO}_{2}$ significantly augmented the As induced toxicity in both cell types.

\section{Co-exposure to $\mathrm{SiO}_{2}$ and MMS causes DNA} damage in a synergistic way.

Additive/ synergistic

(Dussert et al., 2020)
Ahamed et al.

\section{rar}

\section{Studies targeting the cardiovascular system}

\section{Yang et al.}

Co-exposure of silica nanoparticles and methylmercury induced cardiac toxicity in vitro and in vivo
Additive and synergistic interactions were responsible for the cardiac toxicity induced by co-exposure of SiNPs and $\mathrm{MeHg}$ in vitro and in vivo.
Additive/ (Yang et al., synergistic 2018)
Additive/ (Ahamed et

synergistic al., 2020a)
(SiNPs) and

(MeHg)
Rats and human (AC16)
Non-cytotoxic concentration of $\mathrm{nTiO}_{2}$ enhanced the toxicological potential of $\mathrm{Cd}$ in human cells.

\section{Additive/ (Ahamed et synergistic al., 2019b)}



Co-exposure subacute toxicity of silica
Feng et al.
nanoparticles and lead acetate on
cardiovascular system

Low-dose combined exposure of nanoparticles and heavy metal compared with $\mathrm{PM}(2.5)$ in human myocardial AC16 cells

Combined effect of silica nanoparticles and benzo[a]pyrene on cell cycle arrest induction and apoptosis in human umbilical vein endothelial cells
Silica NPs (SiNPs) and lead acetate $(\mathrm{Pb})$

Silica NPs (SiNPs) and lead acetate $\mathrm{Pb}(\mathrm{AC}) 2$; carbon

black nanoparticles

(CBNPs) and

$\mathrm{Pb}(\mathrm{AC}) 2$; SiNPs and CBNPs

Silica NPs (SiNPs)

and Benzo[a]pyrene (B[a]P)

Rats

Co-exposure to SiNPs and $\mathrm{Pb}$ could aggravate the cardiovascular toxicity and cardiac injury in vivo.

Additive/ synergistic

(Feng et al. 2018)

The combination of SiNPs and

$\mathrm{Pb}$ (AC)2/CBNPs as well as the combination of CBNPs and $\mathrm{Pb}(\mathrm{AC}) 2$ resulted in increased toxicity via additive and synergistic

Additive/ synergistic

(Feng et al., cells (AC16) interactions.

Human umbilical vascular endothelial cells (HUVEC)
Interactions between SiNPs and B[a]P

synergistically potentiated toxicological effects on HUVECs.
Additive/

synergistic
(Asweto et

al., 2017)

\section{Studies targeting other systems}

\begin{tabular}{|c|c|}
\hline Roje et al. & $\begin{array}{c}\text { Synergistic effects of parabens and } \\
\text { plastic nanoparticles on proliferation of } \\
\text { human breast cancer cells }\end{array}$ \\
\hline Lai et al. & $\begin{array}{l}\text { Coexposed nanoparticulate } \mathrm{Ag} \\
\text { alleviates the acute toxicity induced by } \\
\text { ionic } \mathrm{Ag}(+) \text { in vivo }\end{array}$ \\
\hline Schirinzi et al. & $\begin{array}{l}\text { Cytotoxic effects of commonly used } \\
\text { nanomaterials and microplastics on } \\
\text { cerebral and epithelial human cells }\end{array}$ \\
\hline Xia B et al. & $\begin{array}{c}\text { Cellular oxidative damage of } \\
\text { HEK293T cells induced by } \\
\text { combination of } \mathrm{CdCl}(2) \text { and nano-TiO }\end{array}$ \\
\hline
\end{tabular}

(2)

$\begin{array}{cc}\text { Plastic NPs and } & \text { Breast cancer cell } \\ \text { parabens } & \text { lines (MDA-MB 231 } \\ \text { and MCF-7) }\end{array}$

Nanoparticulate and ionic silver: AgNPs and $\mathrm{Ag}^{+}$

Fullerenes and malathion, sodium dodecylbenzenesulfo nate and diethyl phthalate

\section{Titanium dioxide}

$$
\text { NPs }
$$

(nano- $\mathrm{TiO}_{2}$ ) and cadmium chloride $\left(\mathrm{CdCl}_{2}\right)$
Human cerebral

$$
\text { (T98G) }
$$

and epithelial (HeLa) cells
Human embryo kidney 293T cells (HEK293T)

Parabens increased proliferation of oestrogensensitive breast cancer cells, and this effect became synergistic in the presence of plastic nanoparticles.

Additive/ (Roje et al. synergistic 2019)

Rats AgNPs reduced the $\mathrm{Ag}^{+}$induced toxicity. Antagonistic $\quad \begin{array}{r}\text { (Lai et al., } \\ \text { 2020) }\end{array}$

Fullerene presented a predominantly antagonistic effect in binary mixtures with other organic contaminants.
Antagonistic (Schirinzi et al., 2017)
$\mathrm{CdCl}_{2}$ and nano- $\mathrm{TiO}_{2}$ exert synergistic effects on the cellular oxidative damage of HEK293T cells.
Additive/ synergistic
(Xia et al., 2011) 
Oral co-exposures to zinc oxide nanoparticles and $\mathrm{CdCl}(2)$ induced maternal-fetal pollutant transfer and embryotoxicity by damaging placental barriers

In vitro co-exposure to $\mathrm{CeO}(2)$

nanomaterials from diesel engine exhaust and benzo(a)pyrene induces additive DNA damage in sperm and cumulus cells but not in oocytes Synergistic effects of particulate matter $(\mathrm{PM}(2.5))$ and sulfur dioxide $(\mathrm{SO}(2))$

on neurodegeneration via the microRNA-mediated regulation of tau phosphorylation

Interaction of gold nanoparticles and nickel(II) sulfate affects dendritic cell maturation

Urban dust particulate matter alters

PAH-induced carcinogenesis by inhibition of CYP1A1 and CYP1B1
Zinc oxide NPs ( $\mathrm{ZnO}$

NPs) and cadmium

chloride $(\mathrm{CdCl} 2)$

Pregnant mice

Synergistic embryotoxicity by nanoparticle/ pollutant combination.

Additive/

(Teng et al.

synergistic 2020)

Cerium dioxide

nanomaterials $\left(\mathrm{CeO}_{2}\right.$

NMs) and

Human (sperm) and

rat gametes: sperm

and cumulus

Benzo(a)pyrene

(oocytes) cells

(BaP)

Particulate matter

(PM2.5) and sulfur

Mice and primary

dioxide $\left(\mathrm{SO}_{2}\right)$

cortical neurons

$\left(\mathrm{SO}_{2}\right)$ co-exposure synergistically leads to neurodegeneration.

Additive/

synergistic

Ku et al., 2017)
Gold NPs (GNPs)

and nickel (II) sulfate $\left(\mathrm{NiSO}_{4}\right)$

Dendritic cells and $\mathrm{NiSO}_{4}$, the observed cell activation pattern indicated a competitive rather than an additive effect of both inducers.

UDPM significantly delayed the onset of $\mathrm{B}$ [a]P-induced tumor initiation. When co-

Benzo[a]pyrene $(\mathrm{B}[\mathrm{a}] \mathrm{P})$,

dibenzo[a,l]pyrene

(DB[a,1]P) and urban

Mice matter (UDPM) reated with UDPM, DB[a,1]P-treated animal displayed no significant difference in tumorinitiating activity, compared with $\mathrm{DB}[\mathrm{a}, 1] \mathrm{P}$ alone. Co-treatment of UDPM plus B[a]P or $\mathrm{DB}[\mathrm{a}, 1] \mathrm{P}$ resulted in increased DNA strand breaks, compared with PAH treatment alone.
Antagonistic

(Deville et

al., 2016)

Both

(Courter et

al., 2007) 
Table 2 - Main parameters considered in our literature review. The proportion of the selected studies related to each parameter is reported. For the biological endpoints, the percentage of studies assessing the indicated variables is indicated. NP: nanoparticle.

\begin{tabular}{|c|c|c|c|c|}
\hline $\begin{array}{c}\text { Nature of the } \\
\text { mixture } \\
\text { studied } \\
\end{array}$ & $\begin{array}{c}\text { Biological } \\
\text { models used }\end{array}$ & $\begin{array}{c}\text { Target organs } \\
\text { investigated }\end{array}$ & $\begin{array}{l}\text { Biological endpoints } \\
\text { mainly assessed }\end{array}$ & $\begin{array}{c}\text { Nature of the effects } \\
\text { observed }\end{array}$ \\
\hline $\begin{array}{l}\text { NP/NP } 10 \% \\
\text { NP/other } 85 \% \\
\text { Both } 5 \%\end{array}$ & $\begin{array}{l}\text { In vitro } 77 \% \\
\text { In vivo } 15 \% \\
\text { Both } 8 \%\end{array}$ & $\begin{array}{l}\text { Respiratory } 54 \% \\
\text { Digestive } 13 \% \\
\text { Cardiovascular 10\% } \\
\text { Other/various } 23 \%\end{array}$ & $\begin{array}{l}\text { Cell viability/ } \\
\text { cytotoxicity } 67 \% \\
\text { Oxidative stress } 59 \% \\
\text { Apoptosis } 46 \% \\
\text { Genotoxicity } 33 \% \\
\text { Cell cycle } 18 \% \\
\text { Cell/organ injury } 15 \% \\
\text { Cell proliferation } 10 \% \\
\text { Inflammation } 10 \% \\
\text { Immunotoxicity } 5 \% \\
\text { Carcinogenesis } 5 \%\end{array}$ & $\begin{array}{l}\text { Additive/synergistic } 64 \% \\
\text { Antagonistic } 23 \% \\
\text { Both (depending on the } \\
\text { model or parameter } \\
\text { assessed) } 8 \% \\
\text { No effect } 5 \%\end{array}$ \\
\hline
\end{tabular}

We first analyzed the type of mixture investigated, indeed, nanoparticles can be co-exposed with a wide variety of compounds including organic contaminants, metal/metalloid ions, inorganic ligands, or other nanoparticles (Deng et al., 2017).

It clearly appeared that the toxicity from multiple nanoparticles exposure was poorly investigated. Indeed, only $10 \%$ of the studies investigated the joint toxicity upon exposure to two types of nanoparticles (Feng et al., 2017; Guo et al., 2021; He et al., 2020; Köerich et al., 2020; Lee et al., 2021; Rosário et al., 2020).

This overlooked type of mixture can however provide critical information. For instance, while investigating the combined effects of zinc oxide nanoparticles (ZnONPs) and copper nanoparticles (CuNPs) in a human hepatoma cell line Li et al. observed that the cytotoxic effect of CuNPs was significantly enhanced by the ZnONPs. However, the cytotoxicity triggered by 
CuNPs was not affected by co-incubation with medium containing only zinc ions, indicating that the increase in toxicity might be attributed to the particle form of ZnONPs (Li et al., 2015). Therefore, the study of binary mixtures of nanoparticles seems highly relevant to better understand the combined toxicity of pollutants.

Only two papers reported both binary mixture of nanoparticles and nanoparticle/other compound (Feng et al., 2017; Rosário et al., 2020).

Much more data is available on the toxicity induced by a co-exposure of a nanoparticle and another compound. Indeed, nanoparticles have been associated with organic contaminants, metal/metalloid ions, inorganic ligands, thus studies reported the joint effects of nanoparticles and common environmental pollutants such as polycyclic aromatic hydrocarbons (PAHs), metal, chemicals, insecticide, pesticide, surfactant, plasticizer, plastics, paraben, preservatives, etc. (For further details, please refer to Supporting Information).

Interestingly, no combination nanoparticle/gas was reported, maybe because this association is technically challenging to reproduce. Wang et al. generated aerosols constituted by silica nanoparticles and bisulfate to simulate a model of particle-associated high-sulfur air pollution. They used bisulfate-coated silica nanoparticles $\left(\mathrm{SiO}_{2}-\mathrm{NH}_{2} @ \mathrm{HSO}_{3}\right)$ and compared their effects to those produced by nano-silica or bisulfite aerosol individually (Wang et al., 2019).

We then analyzed the biological models used and target organs investigated in these studies of combined toxicity. Regarding the biological systems, we clearly observed that the vast majority of the studies were performed using in vitro models, only $15 \%$ used in vivo models and even fewer used a combined approach (8\%). Studies mainly targeted the respiratory system, which seems quite logical considering that they were carried out in a context of air pollution. Indeed, as mentioned before, this topic is a major public health issue worldwide as it has been reported that air pollution is a complex, multi-source mixture of gases and particulate matter, containing 
organic and inorganic compounds. It is recognized as a significant cause of adverse effects on human health, leading to illnesses and being responsible for millions of premature deaths (Guo et al., 2021; Son et al., 2020; WHO, 2014). As the respiratory tract is directly exposed to the atmospheric environment it represents a target of choice for studies aiming to assess the toxicity of air pollutants. The small size of nanoparticles facilitates their entry into the lungs and they can even reach its deepest structures, the alveoli, where they can accumulate if not cleared. As the toxic compounds can adsorb at the surface of the nanoparticles they can benefit from the carrier effect and reach the alveoli, causing further damages (the underlying mechanism will be further described in the next section) (Lu et al., 2015).

Still because of their small size, nanoparticles can translocate and reach the systemic circulation to be potentially distributed to other organs. This explains why some studies investigated the damages to the cardio-vascular system (Asweto et al., 2017; Feng et al., 2018, 2017; Yang et al., 2018) and to other organs (Cotena et al., 2021; Courter et al., 2007; Deville et al., 2016; Ku et al., 2017; Lai et al., 2020; Roje et al., 2019; Schirinzi et al., 2017; Teng et al., 2020; Xia et al., 2011).

Among the different organs, the digestive system is quite well studied (Ahamed et al., 2020a, 2019b; Cao et al., 2021, 2019; Dussert et al., 2020; Shi et al., 2010; Zheng et al., 2012). Indeed, inhaled nanoparticles can reach this system after translocation or due to swallowing after mucocilliary clearance of particles from the airways. They can also be ingested directly as nanoparticles are widely used as additives in cosmetics, toothpaste, food industry, pharmaceuticals, or water treatment. This is especially the case for silica (E551) and titanium dioxide (E171) nanoparticles. Nanoparticles can also be included in products in contact with food (food containers or packaging) and be found in presence of other environmental contaminants such as traces of pesticides (Shi et al., 2010), arsenic (Ahamed et al., 2019b), bisphenol A (Zheng et al., 2012), cadmium (Ahamed et al., 2020a), or benzopyrene (Dussert et 
al., 2020). Cao et al. clearly highlighted that co-exposure to E551 or E171 and the pesticide boscalid increased the cytotoxicity and bioavailability of the pesticide in a model of small intestine epithelium. They further demonstrated an increased translocation of the intestinal barrier correlated to altered cell junctions (Cao et al., 2021, 2019).

In Table 2, the category other/ various includes studies on the nervous system (Ku et al., 2017; Schirinzi et al., 2017), immune system (Deville et al., 2016), kidney cells (Xia et al., 2011), breast cells (Roje et al., 2019), on carcinogenesis (Courter et al., 2007), reproductive organs (Cotena et al., 2021), fetus (Teng et al., 2020) or deal with global effects, affecting several organs (Courter et al., 2007; Lai et al., 2020; Teng et al., 2020).

We then considered the biological endpoints mainly used in these studies. Cell viability/cytotoxicity was the most commonly assessed biological endpoint (evaluated in 67\% of the studies), followed by oxidative stress, a mechanism usually associated with cell damages caused by nanoparticles. This latter includes the assessment of different parameters such as the pro-oxidants generation (reactive oxygen species and lipid peroxidation which is a cellular effect induced by these radicals) and antioxidants depletion (glutathione level, and glutathione reductase, superoxide dismutase and catalase activities). Apoptosis (as reported by the upregulation of caspases and pro-apoptotic members of the Bcl-2 family and the downregulation of anti-apoptotic members of the Bcl-2 family) and genotoxicity (as evaluated by DNA damages) are also frequently investigated. Finally, in less than $20 \%$ of the cases were studied parameters such as cell cycle, cell/organ injuries, cell proliferation, inflammation (secretion of pro-inflammatory cytokines), immunotoxicity (effects on cells from the immune system) or impacts on carcinogenesis. 
Finally, we evaluated the nature of the biological effects observed following a co-exposure to nanoparticles and a co-contaminant. Most of the selected studies reported that co-exposure of nanoparticles and co-contaminant potentiated the biological effects compared to the effects of each compound assessed individually. Additive and/or synergistic effects were indeed observed in $64 \%$ of the cases. On the contrary, protective, antagonistic effects were observed in $23 \%$ of the studies. It should also be mentioned that sometimes no effect was observed (Guo et al., 2021; He et al., 2020) or opposite effects could be shown depending on the nature of the mixture, the biological model or the biological endpoint considered (Cotena et al., 2021; Courter et al., 2007; Lee et al., 2019).

\section{Underlying mechanisms of combined nanoparticle/other contaminant toxicity}

Considering the simultaneous presence of nanoparticles and other pollutants in the environment, various kinds of interactions may occur. In particular, because nanoparticles are characterized by a huge surface/volume ratio, they can adsorb compounds on their surface, either through hydrophobic, electrostatic, $\pi-\pi$ stacking, covalent and/or hydrogen bonding interactions and/or surface complexation (Deng et al., 2017; Liu et al., 2018). The complexes formed between nanoparticles and contaminants will have a deep impact on their biodistribution, their fate within the organism and eventually on the biological outcome.

Figure 3 schematically summarizes the different mechanisms that can be responsible for the joint toxicity of co-exposed contaminants as discussed below. First, nanoparticle can provide a vehicle for co-contaminants and play the role of carrier. 


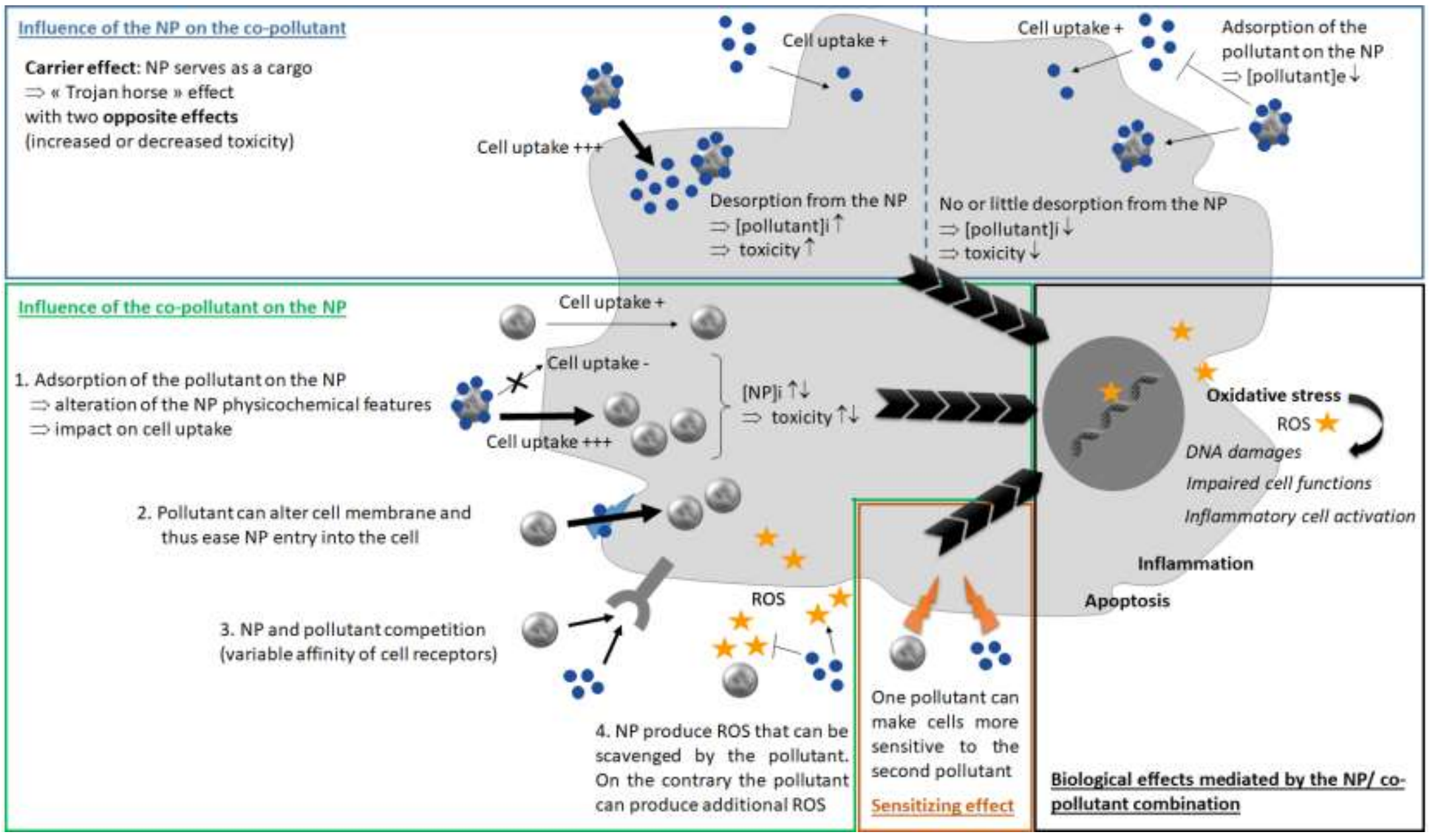

Figure 3 - Summarizing scheme of the potential mechanisms underlying the combined toxicity of nanoparticle and co-pollutant. NP: nanoparticle, [pollutant]i: intracellular concentration of pollutant, [pollutant]e: extracellular concentration of pollutant, [NP]i: intracellular concentration of nanoparticle, ROS: reactive oxygen species, $\downarrow$ : decrease, $\uparrow:$ increase. 


\subsection{A carrier effect leading to increased toxicity}

The capacity of nanoparticles to adsorb a co-pollutant can play a critical role in the toxicity of either the nanoparticle or the pollutant, especially by facilitating the entry of a contaminant in the organism through the uptake of nanoparticle-contaminant complexes. Once inside, the complexed contaminants can be released in the organism increasing their concentration and thus their bioavailability and toxicity. This mechanism is referred to as the "Trojan horse" effect (Deng et al., 2017; Liu et al., 2018). This concept explaining the facilitated entry of toxic molecules adsorbed on nanoparticles and resulting in an enhanced intracellular concentration of pollutants was illustrated by numerous studies (Ahamed et al., 2019b; Dussert et al., 2020; Guo et al., 2013; Roje et al., 2019; Yu et al., 2015; Zheng et al., 2012). For instance, Yu et al. exposed human lung cells to either silica nanoparticles, methylmercury or a combination of both. They observed that the intracellular content of silicon and mercury in the combination group were much higher than those in single exposure groups. This locally increased concentration of methylmercury was correlated with enhanced biological damaging effects ( $\mathrm{Yu}$ et al., 2015). When assessing the combined toxicity of $\mathrm{TiO}_{2}$ nanoparticles and bisphenol $\mathrm{A}$, Zheng et al. observed that because these two compounds formed complexes, they were efficiently taken up by cells, leading to increased intracellular concentrations of both $\mathrm{TiO}_{2}$ nanoparticles and bisphenol A, and ultimately resulting in synergistic toxicity (Zheng et al., 2012). Ahamed et al. also showed a higher intracellular level of arsenic when cells were coexposed with silica nanoparticles compared to cells exposed only to arsenic. In addition, most of the arsenic present in culture media was adsorbed on the surface of the nanoparticles in the co-exposure group, suggesting that nanoparticles can act as a cargo, facilitating arsenic cellular uptake and accumulation in cells (Ahamed et al., 2019b). 
Although many studies have reported this carrier effect as responsible for an enhanced cytotoxicity, other have reported the exact opposite, i.e. a protective effect following a nanoparticle/ other contaminant co-exposure.

\subsection{A carrier effect leading to decreased toxicity}

Indeed, the bioavailability, i.e. the accessibility, of a contaminant to the cells will strongly influence the induction of adverse effects. This is why sorption of contaminants by nanoparticles may decrease the bioavailable concentration in the exposure medium, which would subsequently lower the toxicity caused by these contaminants, assuming that the nanoparticle-contaminant complexes do not enter the organism. But even if the complexes are successfully internalized, toxicity may be mitigated if desorption of contaminants from the nanoparticles-contaminant complexes is limited or incomplete (Deng et al., 2017). As an example, Ahamed et al. reported that adverse effects were attenuated in human lung cells coexposed to $\mathrm{TiO}_{2}$ nanoparticles and lead $(\mathrm{Pb})$ compared to cells exposed only to $\mathrm{Pb}$. Cellular uptake experiments showed that nanoparticles facilitated the entry of $\mathrm{Pb}$ into cells but due to strong adsorption free $\mathrm{Pb}$ ions were not available even inside the cells. From these results it was concluded that $\mathrm{TiO}_{2}$ nanoparticles significantly prevented the bioavailability and toxicity of $\mathrm{Pb}$ (Ahamed et al., 2019a). Similarly, Zeng et al. showed in a model of human bronchial cells that $\mathrm{CeO}_{2}$ nanoparticles were able to reduce available arsenite through adsorption, resulting in reduced toxicity (Zeng et al., 2018). Azari et al. also concluded from two studies that benzo[a]pyrene $(\mathrm{B}[\mathrm{a}] \mathrm{P})$ adsorbed on multi-walled carbon nanotubes, resulting in a decrease of the bioavailability of $\mathrm{B}[\mathrm{a}] \mathrm{P}$ and consequently an attenuation of its adverse effects (Azari et al., 2019; Rezazadeh Azari et al., 2019). Similar results were observed with single-walled carbon nanotubes that can adsorb $\mathrm{Pb}$ at their surface leading to a decreased bioavailability and toxicity of $\mathrm{Pb}$ (Ahamed et al., 2020b). Furthermore, we should consider carefully the kinetic aspect in 
these studies as the bioavailability of the co-pollutant depends on its desorption rate and effects may not be observed if too early time points are considered (effects may just be delayed). This underlines the importance of investigating the effects of pollutants co-exposure over a sufficient period.

Therefore, a same mechanism, the adsorption of a contaminant on nanoparticles, can lead to opposite effects, either 1) facilitating the transport into cells or organisms, increasing the cellular dose and amplifying the toxic effect of the contaminant or 2) decreasing its availability, resulting in a reduction of contaminant uptake by organisms (Liu et al., 2018; Rosário et al., 2020; Schirinzi et al., 2017). It adds further complexity to combined toxicology and draws attention on the fact that nanoparticles/ co-contaminants interactions should be considered carefully.

\subsection{Opposite effects depending on the biological models or endpoints considered}

Furthermore, variable effects can be observed depending on the biological models, the biological endpoints or the experimental conditions. For instance, Köerich et al. observed that while additive effects of $\mathrm{ZnO}$ and $\mathrm{Al}_{2} \mathrm{O}_{3}$ nanoparticles were observed on the cytotoxicity on human bronchial cells, effects were less uniform on murine fibroblasts where additive effects were reported only for the lowest concentrations. However, at the highest concentrations antagonistic effects were observed as the cytotoxicity of $\mathrm{ZnO}$ nanoparticles was attenuated in case of co-exposure with $\mathrm{Al}_{2} \mathrm{O}_{3}$ nanoparticles. It suggests concentration and cell line-dependent effects (Köerich et al., 2020). Similarly, the combined effects of cadmium chloride and $\mathrm{TiO}_{2}$ nanoparticles on cellular oxidative damage varied from additive to synergistic depending on the proportion of the compounds in the mixture (Xia et al., 2011).

Such variable effects were also observed in vivo. For example, Courter et al. investigated the effects of a co-exposure to benzo[a]pyrene (B[a]P) and urban dust particulate matter (UDPM) 
on the bioactivation and tumor initiation in an initiation-promotion tumorigenesis model. While UDPM significantly delayed the onset of $\mathrm{B}[\mathrm{a}] \mathrm{P}$-induced tumor initiation, it increased DNA damages compared to those induced by B[a]P alone (Courter et al., 2007). Besides, Teng et al. observed effects dependent on the timing of exposure. Indeed, they assessed the combined toxicity of zinc oxide nanoparticles and cadmium chloride using two pregnant mice models established by oral administration during peri-implantation or organogenesis period. They observed that exposures to combined pollutants only at organogenesis stage induced higher fetal deformity rate compared to co-exposures at peri-implantation stage (Teng et al., 2020). Cotena et al. showed that co-exposure to $\mathrm{CeO}_{2}$ nanoparticles and benzo[a]pyrene induced additive DNA damage in sperm and cumulus cells compared to those generated by the individual pollutants, whereas no additive toxic effect was observed in rat oocytes. They attributed this result to the structural protection of the oocyte by cumulus cells and to the oocyte's efficient system to repair DNA damage compared to that of cumulus and sperm cells (Cotena et al., 2021).

Also at a population level, co-exposure to pollutants can impact differently individuals, especially in susceptible populations. Jia et al. investigated the joint toxicity of zinc oxide nanoparticles and lead in healthy overweight and healthy normal weight mice. Co-exposure resulted in an increased deposition of lead in all major organs in the overweight mice compared to that in the normal mice and was consequently associated with an enhanced toxicity in overweight mice (Jia et al., 2017).

\subsection{Effects of the co-pollutant on the nanoparticles}

\subsubsection{Direct effects}

So far, we discussed the influence of nanoparticles on the accumulation and toxicity of coexposed contaminants, but the reverse relationship should also be considered. Indeed, 
contaminants can alter the physicochemical features of nanoparticles, especially in relation with surface properties (chemistry, charge, hydrophobicity, agglomeration state, etc.) and consequently result in a modified toxicological profile. As an example, Deville et al. examined the impact of a combined exposure of nickel (II) sulfate $\left(\mathrm{NiSO}_{4}\right)$ and gold nanoparticles (GNPs) on the maturation response of dendritic cells. Antagonistic effects were observed although GNPs and $\mathrm{NiSO}_{4}$ were shown not to directly interact with each other. A further physiochemical characterization allowed to conclude that the presence of $\mathrm{NiSO}_{4}$ induced changes in GNPs' charge and their associated protein corona (content and composition). This latter, as the new nano/bio interface is acknowledged to play a key role in cell/ nanoparticle interactions (Forest, 2019; Forest et al., 2015; Forest and Pourchez, 2017). This alteration could contribute to a decreased cellular uptake of GNPs, sustaining the nickel-induced dendritic cells maturation (Deville et al., 2016). Similarly, Teng et al. observed that the surface charge of $\mathrm{ZnO}$ nanoparticles was modified in case of co-exposure with cadmium chloride (because of $\mathrm{Cd}^{2+}$ adsorption at the nanoparticle surface), promoting enhanced maternal-fetal transfer of both pollutants and aggravated embryotoxicity (Teng et al., 2020).

Finally, functional groups present at the surface of the nanoparticles can be modified by cocontaminant, resulting in an altered toxicity (Deng et al., 2017).

\subsubsection{Indirect effects}

Co-exposed pollutant can impact the cell membrane (in terms of hydrophobicity, fluidity, permeability or physical integrity) leading to an enhanced nanoparticle internalization and toxicity (Deng et al., 2017; Liu et al., 2018). Similarly, exocytosis can be impaired by a pollutant, leading to intracellular accumulation of nanoparticles, enhancing their bioavailability and thus their potential adverse effects (Deng et al., 2017). Some pollutants can also directly affect the physiological activities of organisms and change receptor tolerance to the 
nanoparticles. As an example, Dhasmana et al. showed that benzo[a]pyrene (BaP) entered lung carcinoma cell nucleus via aromatic hydrocarbon receptors, but $\mathrm{TiO}_{2}$ nanoparticles having a higher binding affinity for these receptors than $\mathrm{BaP}$, they reduced nuclear internalization and cytotoxicity of $\mathrm{BaP}$ upon co-exposure (Dhasmana et al., 2014). Other contaminants can mitigate nanoparticles toxicity by scavenging the reactive oxygen species (ROS) the latter produce. On the contrary, contaminants can potentiate nanoparticles adverse effects by generating additional ROS production (Deng et al., 2017).

\subsection{Sensitizing effect}

Another mechanism that can contribute to an enhanced toxicity in case of combined exposure to different pollutants is that one of them can make the cells more sensitive to the second one. This is what observed Jiang et al. suggesting that the intracellular perturbations caused by black carbon made the cells susceptible to lead toxicity (Jiang et al., 2020). Li et al. described that by accumulating in cells, zinc oxide nanoparticles altered cell membranes and enhanced the toxicity of co-exposed copper nanoparticles (Li et al., 2015).

\subsection{Oxidative stress, inflammation, DNA damage and cell death}

Oxidative stress and inflammation have been shown to be two major mechanisms involved in the toxicity of nanoparticles. In addition, they seem to act synergistically to amplify each other's effects (Leni et al., 2020; Miller et al., 2012; Miller and Newby, 2020).

Oxidative stress corresponds to excessive reactive oxygen species (ROS), overwhelming the organism's antioxidant defense system. ROS can lead to cell damages, including DNA damages, and impaired cell functions (Miller et al., 2012). ROS can activate inflammatory cells and oxidize circulating lipids, promoting their accumulation (Miller et al., 2012). 
Inflammatory cells within the lung represent the first line of defense against inhaled pollutants. In particular, alveolar macrophages are responsible for the uptake and clearance of foreign particles. When the phagocytic capacities of the macrophages are exceeded (because of an accumulation of particles or because of a too high particle concentration), cells from the immune system are stimulated continuously, leading to a chronic inflammation (Miller and Newby, 2020).

In addition, the smallest particles are more reactive and more prone to penetrate deeply in the lungs, up to the alveoli, where they can cross the lung epithelial barrier and enter the blood circulation (particle translocation), to be distributed to other organs, explaining extrapulmonary effects (Miller and Newby, 2020).

Oxidative stress has been shown to be a major contributor to the toxicity induced by a combined exposure to carbon black and maghemite iron oxide $\left(\mathrm{Fe}_{2} \mathrm{O}_{3}\right)$ nanoparticles on human lung epithelial cells. Indeed, whereas exposure to either nanomaterial alone induced no significant oxidative stress, the simultaneous exposure to both materials induced a synergistic oxidative stress which was largely attributed to the surface reductive capacity of the carbon black nanoparticles. This latter enabled redox cycling of the iron ions and hence caused significant oxidative stress in cells (Berg et al., 2010).

Oxidative stress can also lead to DNA damages. When these latter are too severe to be repaired by the cellular systems, cell death will occur (Silins and Högberg, 2011; Yu et al., 2015).

\section{Conclusion}

The current literature on the joint toxicity of nanoparticles and co-contaminants is still limited. Moreover, contradictory findings have been reported making it difficult to draw firm conclusions. Co-exposure to different compounds may induce unexpected toxic effects, even if their individual toxicities are well known. Consequently, the estimation of the combined 
toxicity of two compounds based only on their toxicity characterized separately can potentially lead to underestimation. Although the issue is complex (there are countless potential mixtures in our environment) and can be technically challenging to study, it appears of paramount importance to take into account the mixture effects to be more representative of real-life conditions. However, this layer of complexity is often overlooked, using simplified models leading to a reductionist view of the problem. It argues for an urgent need to get data on that topic for a better and reliable sanitary risk assessment and management. It could be starting by binary mixtures and moving forward to mix of increasing complexity to be more representative of the interactions existing between various environmental pollutants (i.e. multilayered combination of exposures, beyond combinations of two factors alone to mimic more realistic exposure scenarios). Introducing incrementally such layers of complexity can unveil effects hidden when using simplified models. Exposomics could also greatly contribute to provide relevant information for the accurate environmental risk assessment of multi-pollutant exposure.

\section{Funding}

This research did not receive any specific grant from funding agencies in the public, commercial, or not-for-profit sectors. 


\section{References}

Abbas, Q., Yousaf, B., Amina, Ali, M.U., Munir, M.A.M., El-Naggar, A., Rinklebe, J., Naushad, M., 2020. Transformation pathways and fate of engineered nanoparticles (ENPs) in distinct interactive environmental compartments: A review. Environ. Int. 138, 105646. https://doi.org/10.1016/j.envint.2020.105646

Ahamed, M., Akhtar, M.J., Alaizeri, Z.M., Alhadlaq, H.A., 2020a. TiO2 nanoparticles potentiated the cytotoxicity, oxidative stress and apoptosis response of cadmium in two different human cells. Environ. Sci. Pollut. Res. Int. 27, 10425-10435. https://doi.org/10.1007/s11356-019-07130-6

Ahamed, M., Akhtar, M.J., Alhadlaq, H.A., 2019a. Preventive effect of TiO2 nanoparticles on heavy metal Pb-induced toxicity in human lung epithelial (A549) cells. Toxicol. Vitro Int. J. Publ. Assoc. BIBRA 57, 18-27. https://doi.org/10.1016/j.tiv.2019.02.004

Ahamed, M., Akhtar, M.J., Alhadlaq, H.A., 2019b. Co-Exposure to SiO2 Nanoparticles and Arsenic Induced Augmentation of Oxidative Stress and Mitochondria-Dependent Apoptosis in Human Cells. Int. J. Environ. Res. Public. Health 16. https://doi.org/10.3390/ijerph16173199

Ahamed, M., Akhtar, M.J., Khan, M.A.M., 2020b. Single-Walled Carbon Nanotubes Attenuate Cytotoxic and Oxidative Stress Response of Pb in Human Lung Epithelial (A549) Cells. Int. J. Environ. Res. Public. Health 17. https://doi.org/10.3390/ijerph17218221

Amigou, A., Sermage-Faure, C., Orsi, L., Leverger, G., Baruchel, A., Bertrand, Y., Nelken, B., Robert, A., Michel, G., Margueritte, G., Perel, Y., Mechinaud, F., Bordigoni, P., Hémon, D., Clavel, J., 2011. Road traffic and childhood leukemia: the ESCALE study (SFCE). Environ. Health Perspect. 119, 566-572. https://doi.org/10.1289/ehp.1002429 Asweto, C.O., Wu, J., Hu, H., Feng, L., Yang, X., Duan, J., Sun, Z., 2017. Combined Effect of Silica Nanoparticles and Benzo[a]pyrene on Cell Cycle Arrest Induction and Apoptosis 
in Human Umbilical Vein Endothelial Cells. Int. J. Environ. Res. Public. Health 14. https://doi.org/10.3390/ijerph14030289

Azari, M.R., Mohammadian, Y., Peirovi, H., Omidi, M., Khodagholi, F., Pourahmad, J., Mehrabi, Y., Rafieepour, A., 2019. Antagonistic effect of co-exposure to shortmultiwalled carbon nanotubes and benzo[a]pyrene in human lung cells (A549). Toxicol. Ind. Health 35, 445-456. https://doi.org/10.1177/0748233719854570

Azari, M.R., Mohammadian, Y., Pourahmad, J., Khodagholi, F., Mehrabi, Y., 2020. Additive toxicity of Co-exposure to pristine multi-walled carbon nanotubes and benzo $\alpha$ pyrene in lung cells. Environ. Res. 183, 109219. https://doi.org/10.1016/j.envres.2020.109219

Ballesteros, S., Barguilla, I., Marcos, R., Hernández, A., 2021. Nanoceria, alone or in combination with cigarette-smoke condensate, induce transforming and epigenetic cancer-like features in vitro. Nanomed. 16, 293-305. https://doi.org/10.2217/nnm2020-0367

Beelen, R., Stafoggia, M., Raaschou-Nielsen, O., Andersen, Z.J., Xun, W.W., Katsouyanni, K., Dimakopoulou, K., Brunekreef, B., Weinmayr, G., Hoffmann, B., Wolf, K., Samoli, E., Houthuijs, D., Nieuwenhuijsen, M., Oudin, A., Forsberg, B., Olsson, D., Salomaa, V., Lanki, T., Yli-Tuomi, T., Oftedal, B., Aamodt, G., Nafstad, P., De Faire, U., Pedersen, N.L., Östenson, C.-G., Fratiglioni, L., Penell, J., Korek, M., Pyko, A., Eriksen, K.T., Tjønneland, A., Becker, T., Eeftens, M., Bots, M., Meliefste, K., Wang, M., Bueno-deMesquita, B., Sugiri, D., Krämer, U., Heinrich, J., de Hoogh, K., Key, T., Peters, A., Cyrys, J., Concin, H., Nagel, G., Ineichen, A., Schaffner, E., Probst-Hensch, N., Dratva, J., Ducret-Stich, R., Vilier, A., Clavel-Chapelon, F., Stempfelet, M., Grioni, S., Krogh, V., Tsai, M.-Y., Marcon, A., Ricceri, F., Sacerdote, C., Galassi, C., Migliore, E., Ranzi, A., Cesaroni, G., Badaloni, C., Forastiere, F., Tamayo, I., Amiano, P., Dorronsoro, M., Katsoulis, M., Trichopoulou, A., Vineis, P., Hoek, G., 2014. Long-term exposure to air 
pollution and cardiovascular mortality: an analysis of 22 European cohorts. Epidemiol. Camb. Mass 25, 368-378. https://doi.org/10.1097/EDE.0000000000000076

Berg, J.M., Ho, S., Hwang, W., Zebda, R., Cummins, K., Soriaga, M.P., Taylor, R., Guo, B., Sayes, C.M., 2010. Internalization of Carbon Black and Maghemite Iron Oxide Nanoparticle Mixtures Leads to Oxidant Production. Chem. Res. Toxicol. 23, 18741882. https://doi.org/10.1021/tx100307h

Brunekreef, B., Holgate, S.T., 2002. Air pollution and health. Lancet Lond. Engl. 360, 12331242. https://doi.org/10.1016/S0140-6736(02)11274-8

Cao, X., DeLoid, G.M., Bitounis, D., Torre-Roche, R.D.L., White, J.C., Zhang, Z., Ho, C.G., Ng, K.W., Eitzer, B.D., Demokritou, P., 2019. Co-exposure to the food additives SiO2 (E551) or $\mathrm{TiO} 2$ (E171) and the pesticide boscalid increases cytotoxicity and bioavailability of the pesticide in a tri-culture small intestinal epithelium model: potential health implications. Environ. Sci. Nano 6, 2786-2800. https://doi.org/10.1039/C9EN00676A

Cao, X., Khare, S., DeLoid, G.M., Gokulan, K., Demokritou, P., 2021. Co-exposure to boscalid and $\mathrm{TiO} 2(\mathrm{E} 171)$ or $\mathrm{SiO} 2$ (E551) downregulates cell junction gene expression in small intestinal epithelium cellular model and increases pesticide translocation. NanoImpact 22, 100306. https://doi.org/10.1016/j.impact.2021.100306

Carlsten, C., 2018. Synergistic Environmental Exposures and the Airways Capturing Complexity in Humans: An Underappreciated World of Complex Exposures. Chest 154, 918-924. https://doi.org/10.1016/j.chest.2018.06.004

Cedergreen, N., 2014. Quantifying Synergy: A Systematic Review of Mixture Toxicity Studies within Environmental Toxicology. PLOS ONE 9, e96580. https://doi.org/10.1371/journal.pone.0096580 
Chalbot, M.-C.G., Pirela, S.V., Schifman, L., Kasaraneni, V., Oyanedel-Craver, V., Bello, D., Castranova, V., Qian, Y., Thomas, T., Kavouras, I.G., Demokritou, P., 2017. Synergistic effects of engineered nanoparticles and organics released from laser printers using nano-enabled toners: potential health implications from exposures to the emitted organic aerosol. Environ. Sci. Nano 4, 2144-2156. https://doi.org/10.1039/C7EN00573C

Chivas-Joly, C., Gaie-Levrel, F., Motzkus, C., Ducourtieux, S., Delvallée, A., De Lagos, F., Nevé, S.L., Gutierrez, J., Lopez-Cuesta, J.-M., 2016. Characterization of aerosols and fibers emitted from composite materials combustion. J. Hazard. Mater. 301, 153-162. https://doi.org/10.1016/j.jhazmat.2015.08.043

Chivas-Joly, C., Longuet, C., Pourchez, J., Leclerc, L., Sarry, G., Lopez-Cuesta, J.-M., 2019. Physical, morphological and chemical modification of Al-based nanofillers in byproducts of incinerated nanocomposites and related biological outcome. J. Hazard. Mater. 365, 405-412. https://doi.org/10.1016/j.jhazmat.2018.10.029

Cotena, M., Auffan, M., Tassistro, V., Resseguier, N., Rose, J., Perrin, J., 2021. In Vitro CoExposure to $\mathrm{CeO} 2$ Nanomaterials from Diesel Engine Exhaust and Benzo(a)Pyrene Induces Additive DNA Damage in Sperm and Cumulus Cells but Not in Oocytes. Nanomater. Basel Switz. 11. https://doi.org/10.3390/nano11020478

Courter, L.A., Musafia-Jeknic, T., Fischer, K., Bildfell, R., Giovanini, J., Pereira, C., Baird, W.M., 2007. Urban dust particulate matter alters PAH-induced carcinogenesis by inhibition of CYP1A1 and CYP1B1. Toxicol. Sci. Off. J. Soc. Toxicol. 95, 63-73. https://doi.org/10.1093/toxsci/kfl137

Deng, R., Lin, D., Zhu, L., Majumdar, S., White, J.C., Gardea-Torresdey, J.L., Xing, B., 2017. Nanoparticle interactions with co-existing contaminants: joint toxicity, bioaccumulation 
and

risk. Nanotoxicology

11,

$591-612$.

https://doi.org/10.1080/17435390.2017.1343404

Deville, S., Baré, B., Piella, J., Tirez, K., Hoet, P., Monopoli, M.P., Dawson, K.A., Puntes, V.F., Nelissen, I., 2016. Interaction of gold nanoparticles and nickel(II) sulfate affects dendritic cell maturation. Nanotoxicology 10, 1395-1403. https://doi.org/10.1080/17435390.2016.1221476

Dhasmana, A., Sajid Jamal, Q.M., Mir, S.S., Bhatt, M.L.B., Rahman, Q., Gupta, R., Siddiqui, M.H., Lohani, M., 2014. Titanium dioxide nanoparticles as guardian against environmental carcinogen benzo[alpha]pyrene. PloS One 9, e107068. https://doi.org/10.1371/journal.pone.0107068

Dockery, D.W., Pope, C.A., Xu, X., Spengler, J.D., Ware, J.H., Fay, M.E., Ferris, B.G., Speizer, F.E., 1993. An association between air pollution and mortality in six U.S. cities. N. Engl. J. Med. 329, 1753-1759. https://doi.org/10.1056/NEJM199312093292401

Dussert, F., Arthaud, P.-A., Arnal, M.-E., Dalzon, B., Torres, A., Douki, T., Herlin, N., Rabilloud, T., Carriere, M., 2020. Toxicity to RAW264.7 Macrophages of Silica Nanoparticles and the E551 Food Additive, in Combination with Genotoxic Agents. Nanomater. Basel Switz. 10. https://doi.org/10.3390/nano10071418

Feng, L., Yang, X., Asweto, C.O., Wu, J., Zhang, Y., Hu, H., Shi, Y., Duan, J., Sun, Z., 2017. Low-dose combined exposure of nanoparticles and heavy metal compared with PM2.5 in human myocardial AC16 cells. Environ. Sci. Pollut. Res. Int. 24, 27767-27777. https://doi.org/10.1007/s11356-017-0228-3

Feng, L., Yang, X., Shi, Y., Liang, S., Zhao, T., Duan, J., Sun, Z., 2018. Co-exposure subacute toxicity of silica nanoparticles and lead acetate on cardiovascular system. Int. J. Nanomedicine 13, 7819-7834. https://doi.org/10.2147/IJN.S185259 
Forest, V., 2019. CHAPTER 2:Biological Significance of the Nanoparticles Protein Corona, in: Nanoparticle-Protein Corona. pp. 31-60. https://doi.org/10.1039/978178801630800031

Forest, V., Cottier, M., Pourchez, J., 2015. Electrostatic interactions favor the binding of positive nanoparticles on cells: A reductive theory. Nano Today 10, 677-680. https://doi.org/10.1016/j.nantod.2015.07.002

Forest, V., Pourchez, J., 2017. Preferential binding of positive nanoparticles on cell membranes is due to electrostatic interactions: A too simplistic explanation that does not take into account the nanoparticle protein corona. Mater. Sci. Eng. C Mater. Biol. Appl. 70, 889896. https://doi.org/10.1016/j.msec.2016.09.016

Germanova, T., Kernozhitskaya, A., 2017. Emissions of exhaust gases and health of the person. IOP Conf. Ser. Earth Environ. Sci. 90, 012036. https://doi.org/10.1088/1755$1315 / 90 / 1 / 012036$

Greim, H., 2019. Diesel engine emissions: are they no longer tolerable? Arch. Toxicol. 93, 2483-2490. https://doi.org/10.1007/s00204-019-02531-5

Guo, C., Weber, R.J.M., Buckley, A., Mazzolini, J., Robertson, S., Delgado-Saborit, J.M., Rappoport, J.Z., Warren, J., Hodgson, A., Sanderson, P., Chipman, J.K., Viant, M.R., Smith, R., 2021. Environmentally Relevant Iron Oxide Nanoparticles Produce Limited Acute Pulmonary Effects in Rats at Realistic Exposure Levels. Int. J. Mol. Sci. 22, 556. https://doi.org/10.3390/ijms22020556

Guo, M., Xu, X., Yan, X., Wang, S., Gao, S., Zhu, S., 2013. In vivo biodistribution and synergistic toxicity of silica nanoparticles and cadmium chloride in mice. J. Hazard. Mater. 260, 780-788. https://doi.org/10.1016/j.jhazmat.2013.06.040 
He, W., Peng, H., Ma, J., Wang, Q., Li, A., Zhang, J., Kong, H., Li, Q., Sun, Y., Zhu, Y., 2020. Autophagy changes in lung tissues of mice at 30 days after carbon black-metal ion coexposure. Cell Prolif. 53, e12813. https://doi.org/10.1111/cpr.12813

Jia, J., Li, F., Zhai, S., Zhou, H., Liu, S., Jiang, G., Yan, B., 2017. Susceptibility of Overweight Mice to Liver Injury as a Result of the ZnO Nanoparticle-Enhanced Liver Deposition of Pb2. Environ. Sci. Technol. 51, 1775-1784. https://doi.org/10.1021/acs.est.6b05200

Jiang, N., Wen, H., Zhou, M., Lei, T., Shen, J., Zhang, D., Wang, R., Wu, H., Jiang, S., Li, W., 2020. Low-dose combined exposure of carboxylated black carbon and heavy metal lead induced potentiation of oxidative stress, DNA damage, inflammation, and apoptosis in BEAS-2B cells. Ecotoxicol. Environ. Saf. 206, 111388. https://doi.org/10.1016/j.ecoenv.2020.111388

Köerich, J.S., Nogueira, D.J., Vaz, V.P., Simioni, C., Silva, M.L.N.D., Ouriques, L.C., Vicentini, D.S., Matias, W.G., 2020. Toxicity of binary mixtures of A12O3 and ZnO nanoparticles toward fibroblast and bronchial epithelium cells. J. Toxicol. Environ. Health A 83, 363-377. https://doi.org/10.1080/15287394.2020.1761496

Ku, T., Chen, M., Li, B., Yun, Y., Li, G., Sang, N., 2017. Synergistic effects of particulate matter (PM2.5) and sulfur dioxide (SO2) on neurodegeneration via the microRNAmediated regulation of tau phosphorylation. Toxicol. Res. 6, 7-16. https://doi.org/10.1039/c6tx00314a

Lai, Y., Dong, L., Zhou, H., Yan, B., Chen, Y., Cai, Y., Liu, J., 2020. Coexposed nanoparticulate Ag alleviates the acute toxicity induced by ionic Ag+in vivo. Sci. Total Environ. 723, 138050. https://doi.org/10.1016/j.scitotenv.2020.138050

Lee, C.-W., Chi, M.-C., Peng, K.-T., Chiang, Y.-C., Hsu, L.-F., Yan, Y.-L., Li, H.-Y., Chen, M.-C., Lee, I.-T., Lai, C.-H., 2019. Water-Soluble Fullerenol C60(OH)36 toward 
Effective Anti-Air Pollution Induced by Urban Particulate Matter in HaCaT Cell. Int. J. Mol. Sci. 20. https://doi.org/10.3390/ijms20174259

Lee, S., Lee, D.-K., Jeon, S., Kim, S.-H., Jeong, J., Kim, J.S., Cho, J.H., Park, H., Cho, W.-S., 2021. Combination effect of nanoparticles on the acute pulmonary inflammogenic potential: additive effect and antagonistic effect. Nanotoxicology 15, 276-288. https://doi.org/10.1080/17435390.2020.1862336

Lehto, M., Karilainen, T., Róg, T., Cramariuc, O., Vanhala, E., Tornaeus, J., Taberman, H., Jänis, J., Alenius, H., Vattulainen, I., Laine, O., 2014. Co-exposure with fullerene may strengthen health effects of organic industrial chemicals. PloS One 9, e114490. https://doi.org/10.1371/journal.pone.0114490

Leni, Z., Künzi, L., Geiser, M., 2020. Air pollution causing oxidative stress. Curr. Opin. Toxicol., $\quad$ Oxidative $\quad$ Toxicology $20-21, \quad 1-8$. https://doi.org/10.1016/j.cotox.2020.02.006

Li, L., Fernández-Cruz, M.L., Connolly, M., Conde, E., Fernández, M., Schuster, M., Navas, J.M., 2015. The potentiation effect makes the difference: non-toxic concentrations of $\mathrm{ZnO}$ nanoparticles enhance $\mathrm{Cu}$ nanoparticle toxicity in vitro. Sci. Total Environ. 505, 253-260. https://doi.org/10.1016/j.scitotenv.2014.10.020

Liu, Y., Nie, Y., Wang, Jingjing, Wang, Juan, Wang, X., Chen, S., Zhao, G., Wu, L., Xu, A., 2018. Mechanisms involved in the impact of engineered nanomaterials on the joint toxicity with environmental pollutants. Ecotoxicol. Environ. Saf. 162, 92-102. https://doi.org/10.1016/j.ecoenv.2018.06.079

Lu, C.-F., Li, L.-Z., Zhou, W., Zhao, J., Wang, Y.-M., Peng, S.-Q., 2017. Silica nanoparticles and lead acetate co-exposure triggered synergistic cytotoxicity in A549 cells through potentiation of mitochondria-dependent apoptosis induction. Environ. Toxicol. Pharmacol. 52, 114-120. https://doi.org/10.1016/j.etap.2017.04.001 
Lu, C.-F., Yuan, X.-Y., Li, L.-Z., Zhou, W., Zhao, J., Wang, Y.-M., Peng, S.-Q., 2015. Combined exposure to nano-silica and lead induced potentiation of oxidative stress and DNA damage in human lung epithelial cells. Ecotoxicol. Environ. Saf. 122, 537-544. https://doi.org/10.1016/j.ecoenv.2015.09.030

Miller, G.W., Jones, D.P., 2014. The nature of nurture: refining the definition of the exposome. Toxicol. Sci. Off. J. Soc. Toxicol. 137, 1-2. https://doi.org/10.1093/toxsci/kft251

Miller, M.R., Newby, D.E., 2020. Air pollution and cardiovascular disease: car sick. Cardiovasc. Res. 116, 279-294. https://doi.org/10.1093/cvr/cvz228

Miller, M.R., Shaw, C.A., Langrish, J.P., 2012. From particles to patients: oxidative stress and the cardiovascular effects of air pollution. Future Cardiol. 8, 577-602. https://doi.org/10.2217/fca.12.43

Niedzwiecki, M.M., Walker, D.I., Vermeulen, R., Chadeau-Hyam, M., Jones, D.P., Miller, G.W., 2019. The Exposome: Molecules to Populations. Annu. Rev. Pharmacol. Toxicol. 59, 107-127. https://doi.org/10.1146/annurev-pharmtox-010818-021315

Rezazadeh Azari, M., Mohammadian, Y., Pourahmad, J., Khodagholi, F., Peirovi, H., Mehrabi, Y., Omidi, M., Rafieepour, A., 2019. Individual and combined toxicity of carboxylic acid functionalized multi-walled carbon nanotubes and benzo a pyrene in lung adenocarcinoma cells. Environ. Sci. Pollut. Res. Int. 26, 12709-12719. https://doi.org/10.1007/s11356-019-04795-x

Roje, Ž., Ilić, K., Galić, E., Pavičić, I., Turčić, P., Stanec, Z., Vrček, I.V., 2019. Synergistic effects of parabens and plastic nanoparticles on proliferation of human breast cancer cells. Arh. Hig. Rada Toksikol. 70, 310-314. https://doi.org/10.2478/aiht-2019-70-3372

Rosário, F., Bessa, M.J., Brandão, F., Costa, C., Lopes, C.B., Estrada, A.C., Tavares, D.S., Teixeira, J.P., Reis, A.T., 2020. Unravelling the Potential Cytotoxic Effects of Metal 
Oxide Nanoparticles and Metal(Loid) Mixtures on A549 Human Cell Line. Nanomater. Basel Switz. 10, 447. https://doi.org/10.3390/nano10030447

Schirinzi, G.F., Pérez-Pomeda, I., Sanchís, J., Rossini, C., Farré, M., Barceló, D., 2017. Cytotoxic effects of commonly used nanomaterials and microplastics on cerebral and epithelial human cells. Environ. Res. 159, 579-587. https://doi.org/10.1016/j.envres.2017.08.043

Shah, A.S., Langrish, J.P., Nair, H., McAllister, D.A., Hunter, A.L., Donaldson, K., Newby, D.E., Mills, N.L., 2013. Global association of air pollution and heart failure: a systematic review and meta-analysis. The Lancet 382, 1039-1048. https://doi.org/10.1016/S0140-6736(13)60898-3

Shi, Y., Zhang, J.-H., Jiang, M., Zhu, L.-H., Tan, H.-Q., Lu, B., 2010. Synergistic genotoxicity caused by low concentration of titanium dioxide nanoparticles and p,p'-DDT in human hepatocytes. Environ. Mol. Mutagen. 51, 192-204. https://doi.org/10.1002/em.20527

Silins, I., Högberg, J., 2011. Combined Toxic Exposures and Human Health: Biomarkers of Exposure and Effect. Int. J. Environ. Res. Public. Health 8, 629-647. https://doi.org/10.3390/ijerph8030629

Singh, D., Schifman, L.A., Watson-Wright, C., Sotiriou, G.A., Oyanedel-Craver, V., Wohlleben, W., Demokritou, P., 2017. Nanofiller Presence Enhances Polycyclic Aromatic Hydrocarbon (PAH) Profile on Nanoparticles Released during Thermal Decomposition of Nano-enabled Thermoplastics: Potential Environmental Health Implications. Environ. Sci. Technol. 51, 5222-5232. https://doi.org/10.1021/acs.est.6b06448

Son, E.S., Park, J.-W., Kim, Y.J., Jeong, S.H., Hong, J.H., Kim, S.-H., Kyung, S.Y., 2020. Effects of antioxidants on oxidative stress and inflammatory responses of human bronchial epithelial cells exposed to particulate matter and cigarette smoke extract. 
Toxicol. Vitro Int. J. Publ. Assoc. BIBRA 67, 104883. https://doi.org/10.1016/j.tiv.2020.104883

Stone, V., Miller, M.R., Clift, M.J.D., Elder, A., Mills, N.L., Møller, P., Schins, R.P.F., Vogel, U., Kreyling, W.G., Alstrup Jensen, K., Kuhlbusch, T.A.J., Schwarze, P.E., Hoet, P., Pietroiusti, A., De Vizcaya-Ruiz, A., Baeza-Squiban, A., Teixeira, J.P., Tran, C.L., Cassee, F.R., 2017. Nanomaterials Versus Ambient Ultrafine Particles: An Opportunity to Exchange Toxicology Knowledge. Environ. Health Perspect. 125, 106002. https://doi.org/10.1289/EHP424

Teng, C., Jia, J., Wang, Z., Yan, B., 2020. Oral Co-Exposures to zinc oxide nanoparticles and $\mathrm{CdCl} 2$ induced maternal-fetal pollutant transfer and embryotoxicity by damaging placental barriers. Ecotoxicol. Environ. Saf. $189, \quad 109956$. https://doi.org/10.1016/j.ecoenv.2019.109956

Vermeulen, R., Schymanski, E.L., Barabási, A.-L., Miller, G.W., 2020. The exposome and health: Where chemistry meets biology. Science 367, 392-396. https://doi.org/10.1126/science.aay3164

Wang, R., Chen, R., Wang, Y., Chen, L., Qiao, J., Bai, R., Ge, G., Qin, G., Chen, C., 2019. Complex to simple: In vitro exposure of particulate matter simulated at the air-liquid interface discloses the health impacts of major air pollutants. Chemosphere 223, 263274. https://doi.org/10.1016/j.chemosphere.2019.02.022

WHO, 2014. Burden of disease from Ambient Air Pollution for 2012.

Wild, C.P., 2005. Complementing the genome with an "exposome": the outstanding challenge of environmental exposure measurement in molecular epidemiology. Cancer Epidemiol. Biomark. Prev. Publ. Am. Assoc. Cancer Res. Cosponsored Am. Soc. Prev. Oncol. 14, 1847-1850. https://doi.org/10.1158/1055-9965.EPI-05-0456 
Wu, J., Shi, Y., Asweto, C.O., Feng, L., Yang, X., Zhang, Y., Hu, H., Duan, J., Sun, Z., 2016. Co-exposure to amorphous silica nanoparticles and benzo[a]pyrene at low level in human bronchial epithelial BEAS-2B cells. Environ. Sci. Pollut. Res. Int. 23, 2313423144. https://doi.org/10.1007/s11356-016-7559-3

Wu, J., Zhang, J., Nie, J., Duan, J., Shi, Y., Feng, L., Yang, X., An, Y., Sun, Z., 2019. The chronic effect of amorphous silica nanoparticles and benzo[a]pyrene co-exposure at low dose in human bronchial epithelial BEAS-2B cells. Toxicol. Res. 8, 731-740. https://doi.org/10.1039/c9tx00112c

Xia, B., Chen, J., Zhou, Y., 2011. Cellular oxidative damage of HEK293T cells induced by combination of $\mathrm{CdCl}(2)$ and nano-TiO (2). J. Huazhong Univ. Sci. Technol. Med. Sci. Hua Zhong Ke Ji Xue Xue Bao Yi Xue Ying Wen Ban Huazhong Keji Daxue Xuebao Yixue Yingdewen Ban 31, 290-294. https://doi.org/10.1007/s11596-011-0369-4

Yang, X., Feng, L., Zhang, Y., Hu, H., Shi, Y., Liang, S., Zhao, T., Cao, L., Duan, J., Sun, Z., 2018. Co-exposure of silica nanoparticles and methylmercury induced cardiac toxicity in vitro and in vivo. Sci. Total Environ. 631-632, 811-821. https://doi.org/10.1016/j.scitotenv.2018.03.107

Yu, Yongbo, Duan, J., Li, Y., Yu, Yang, Jin, M., Li, C., Wang, Y., Sun, Z., 2015. Combined toxicity of amorphous silica nanoparticles and methylmercury to human lung epithelial $\begin{array}{llll}\text { cells. } & \text { Ecotoxicol. } & \text { Environ. } & \text { Saf. }\end{array}$ https://doi.org/10.1016/j.ecoenv.2014.10.026

Yun, Y., Gao, R., Yue, H., Li, G., Zhu, N., Sang, N., 2015. Synergistic effects of particulate matter (PM10) and SO2 on human non-small cell lung cancer A549 via ROS-mediated NF-kB activation. J. Environ. Sci. China 31, 146-153. https://doi.org/10.1016/j.jes.2014.09.041 
Zeng, C., Nguyen, C., Boitano, S., Field, J.A., Shadman, F., Sierra-Alvarez, R., 2018. Cerium dioxide $(\mathrm{CeO} 2)$ nanoparticles decrease arsenite (As(III)) cytotoxicity to $16 \mathrm{HBE} 140-$ human bronchial epithelial cells. Environ. Res. 164, 452-458. https://doi.org/10.1016/j.envres.2018.03.007

Zheng, D., Wang, N., Wang, X., Tang, Y., Zhu, L., Huang, Z., Tang, H., Shi, Y., Wu, Y., Zhang, M., Lu, B., 2012. Effects of the interaction of TiO2 nanoparticles with bisphenol A on their physicochemical properties and in vitro toxicity. J. Hazard. Mater. 199-200, 426432. https://doi.org/10.1016/j.jhazmat.2011.11.040 